\title{
Potential impacts of tephra fallout from a large-scale explosive eruption at Sakurajima volcano, Japan
}

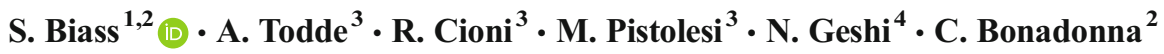

Received: 28 February 2017 / Accepted: 6 September 2017

(C) Springer-Verlag GmbH Germany 2017

\begin{abstract}
We present an exposure analysis of infrastructure and lifeline to tephra fallout for a future large-scale explosive eruption of Sakurajima volcano. An eruption scenario is identified based on the field characterization of the last subplinian eruption at Sakurajima and a review of reports of the eruptions that occurred in the past six centuries. A scenario-based probabilistic hazard assessment is performed using the Tephra2 model, considering various eruption durations to reflect complex eruptive sequences of all considered reference eruptions. A quantitative exposure analysis of infrastructures and lifelines is presented primarily using open-access data. The post-event impact assessment of Magill et al. (Earth Planets Space 65:677-698, 2013) after the 2011 VEI 2 eruption of Shinmoedake is used to discuss the vulnerability and the resilience of infrastructures during a future large eruption of Sakurajima. Results indicate a main eastward dispersal, with longer eruption durations increasing the probability of tephra accumulation in proximal areas and reducing it in distal areas. The exposure analysis reveals that $2300 \mathrm{~km}$ of road network, $18 \mathrm{~km}^{2}$ of urban area, and $306 \mathrm{~km}^{2}$ of agricultural land have a $50 \%$ probability of being affected by an accumulation of tephra of $1 \mathrm{~kg} / \mathrm{m}^{2}$. A simple qualitative exposure analysis
\end{abstract}

Editorial responsibility: L. Sandri

S. Biass

sbiasse@hawaii.edu

1 Department of Geology and Geophysics, University of Hawaii at Manoa, Honolulu, HI, USA

2 Department of Earth Sciences, University of Geneva, Geneva, Switzerland

3 Dipartimento di Scienze della Terra, Università di Firenze, Florence, Italy

4 Geological Survey of Japan, AIST, Tsukuba, Japan suggests that the municipalities of Kagoshima, Kanoya, and Tarumizu are the most likely to suffer impacts. Finally, the 2011 VEI 2 eruption of Shinmoedake demonstrated that the already implemented mitigation strategies have increased resilience and improved recovery of affected infrastructures. Nevertheless, the extent to which these mitigation actions will perform during the VEI 4 eruption presented here is unclear and our hazard assessment points to possible damages on the Sakurajima peninsula and the neighboring municipality of Tarumizu.

Keywords Tephra fallout · Sakurajima volcano · Eruption · Pre-event impact assessment $\cdot$ Hazard assessment

\section{Introduction}

Sakurajima volcano (Kyushu Island, Japan, 31.58 N, 130.65 E; Fig. 1) is located on the southern rim of the Aira Caldera and has been repeatedly active since the 1950 s with daily vulcanian explosions, making it Japan's most active volcano. Seventeen subplinian to Plinian fallout deposits have been identified as part of the Sakurajima sequence since the caldera collapse $\sim 29,000$ years ago, including three during historical times within the last six centuries: the Bunmei (1471-1476 AD), the Anei (1779-1782 AD), and Taisho (1914-1915 AD) eruptions, the latter being the largest eruption in Japan during the twentieth century. All three eruptions were characterized by complex scenarios, dominated by a paroxysmal phase followed by prolonged effusive activity associated with variable ash emission.

Currently, the risk management and evacuation plan for Sakurajima volcano are primarily based on the historical record of the 1914 Taisho eruption. The local government of Kagoshima City first published hazard maps for Sakurajima 

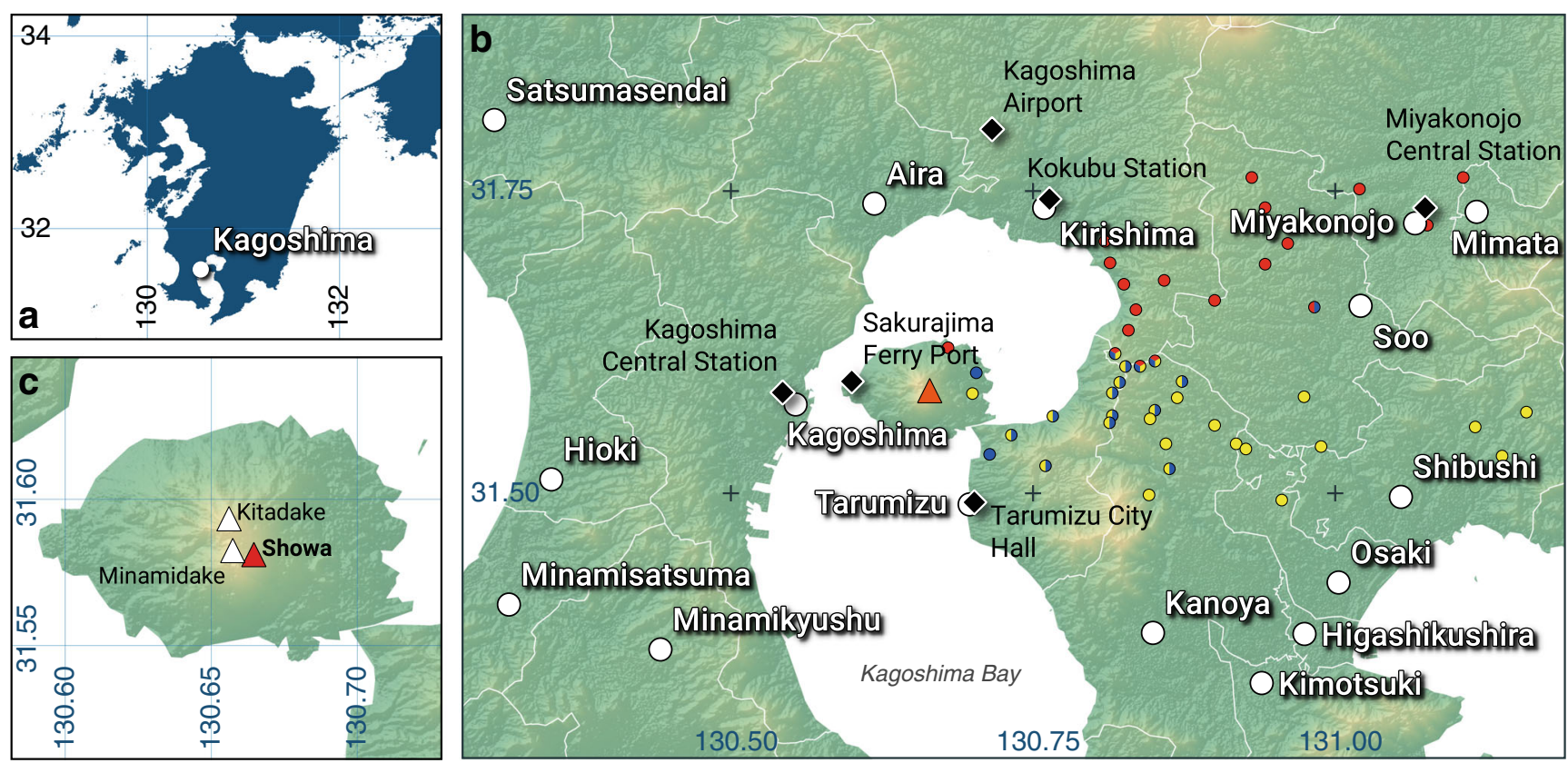

containing the deposits of the Anei (blue), Bunmei (red), and Taisho

Fig. 1 Location map of the study area. a Overview of Kyushu Island. b Study area for out hazard and exposure studies. White dots are the main cities and white borders are the administrative boundaries of the municipalities around the city. Black diamonds are the selected critical infrastructure. Colored points locate the outcrops of Todde et al. (2017) (yellow) eruptions. The red triangle is the vent used in the simulations. c Location of the three summit craters active during historical time. Simulations are centered on the Showa crater

all available data for the 1476 Bunmei and 1779 Anei events to develop for a VEI 4 Plinian eruption scenario (Volcanic Explosivity Index; Newhall and Self 1982). All three eruptions were first reinterpreted using the Tephra2 inversion algorithm of Connor and Connor (2006). To account for the multi-stage nature of the reference eruptions, two eruption scenarios of different durations were assumed and modeled with Tephra2 (Bonadonna et al. 2005; Biass et al. 2016a). Finally, an exposure analysis is presented and discussed in the context of the post-impact assessment of the 2011 eruption of Shinmoedake by Magill et al. (2013) to estimate the potential impact of a future Plinian eruption of Sakurajima volcano.

\section{Geological background}

Sakurajima volcano is located on the southern edge of the Aira Caldera, which lies in the N-S Kagoshima graben fault system. The Aira Caldera has been active over the last 100,000 years with the occurrence of at least four Plinian eruptions, the last being a VEI 7 eruption $\sim 29,000$ years ago that produced $500 \mathrm{~km}^{3}$ of ejecta partitioned between the Osumi pumice fall and the Ito pyroclastic flow (Aramaki 1984; Machida 2002; Kobayashi et al. 2013).

The edifice of Sakurajima started growing 26,000 years ago and is now composed of the juxtaposition of the older Kitadake and the younger Minamidake edifices (Kobayashi et al. 2013; Yasui et al. 2013). Sakurajima has produced 17 
major tephra fallout layers in its eruptive history, four of which occurred during historical times (i.e., since the early sixth century; Kobayashi et al. 2013). The largest occurred $\sim 13,000$ years ago and dispersed a total volume of pyroclastic material of $\sim 11 \mathrm{~km}^{3}$, making it the only eruption with a volume $>2 \mathrm{~km}^{3}$. Since $1955 \mathrm{AD}$, Sakurajima has been repeatedly active with almost daily vulcanian explosions taking place from the Minamidake crater. Since 2006, the focus of activity has shifted mainly to the Showa crater.

\section{Reference eruptions}

Four major eruptions took place at Sakurajima during historical times including the Tenpyo-Hoji (764-766 AD), the Bunmei (1471-1476 AD), the Anei (1779-1782 AD), and the Taisho (1914-1915 AD) eruptions, each named after their corresponding Japanese eras. At least three of these eruptions (Bunmei, Anei, and Taisho) had a subplinian- to Pliniantype paroxysmal phase within complex eruptive sequences. Historical accounts are available for all three eruptions, and the deposits of the paroxysmal explosive and of the effusive phases have now been studied and mapped in detail (Kobayashi et al. 2013; Todde et al. 2017; Todde 2016). Conversely, the Tenpyo-Hoji eruption was mainly characterized by hydromagmatic activity, with the formation of the Nabeyama tuff cone on the southeastern side of the volcano, and by the dispersal of wet fine ash in the Tarumizu County (Kobayashi and Tameike 2002; Kobayashi et al. 2013).

While available chronicles for the Bunmei and Anei eruptions are fragmented and poorly detailed, Omori (1914) and Kotô (1916) give a highly detailed and modern description of the 1914 Taisho eruption including its activity, relative timing, the deposits, and the effects. More recent studies have focused on geophysical precursors (e.g., Yokoama 1997; Igushi 2013) to chemical and mineralogical compositions of the deposits (e.g., Kobayashi and Tameike 2002; Kobayashi et al. 2013; Yasui et al. 2013; Todde et al. 2017). For these reasons, our eruption scenario for Sakurajima is primarily based on the highly detailed eruptive sequence inferred for the 1914 Taisho eruption, and supported by a more fragmented dataset for the older Bunmei and Anei eruptions. Importantly, new data on Plinian-type activity for all the three eruptions are now available (Todde 2016; Todde et al. 2017; Cioni et al. in prep) and were used in the analysis of tephra dispersal hazards. The following sections summarize the eruptive sequences of the Taisho, Bunmei, and Anei eruptions based on the chronicles of Omori (1914) and Kotô (1916). Unless specified otherwise, all statements refer to these chronicles.

\section{The 1914 Taisho subplinian eruption}

The Taisho eruption was the largest eruption in Japan during the twentieth century. Leveling surveys conducted by the
Japanese Imperial Military in 1891-1895 describe a preeruptive uplift similar to the present rate (Hickey et al. 2016). After a long period of quiescence, Sakurajima suddenly reawakened on 10 January 1914 when earthquakes started to be felt on the island. The eruption began around $10 \mathrm{a} . \mathrm{m}$. local time on 12 January, with a first eruptive column from a vent on the west flank of the volcano. After about $10 \mathrm{~min}$, a second plume formed from another vent along a new fissure on the east flank of the volcano. During the eruption, explosive activity was stronger on the eastern flank than on the western flank. The two plumes had already risen to a height of 5-8 $\mathrm{km}$ within an hour of the start of the eruption (Yasui et al. 2013), suggesting a rapid increase in the magma discharge rate. While local seismicity suddenly decreased after the eruption onset, a M7.1 earthquake, possibly of tectonic origin, struck the area in the late afternoon of 12 January, killing 35 people in Kagoshima City. The eruption reached a climax between 11 p.m. on 12 January and 5 a.m. on 13 January, with a peak in intensity around 1 a.m. 13 January producing a plume height estimated as being between $10 \mathrm{~km}$ (Omori 1914) and 18 km (Kotô 1916) above sea level (asl). Based on field data, Todde et al. (2017) estimated the peak height of the subplinian eruptive plume to be around $15 \mathrm{~km}$ asl. Small, topographically controlled pyroclastic flows were generated along the western fissure, possibly during the climactic phase. Based on different classification schemes, the climactic phase straddles the fields between Plinian and subplinian eruptions (Todde et al. 2017). After 10 a.m. on 13 January, the intensity started to decline, although the plume remained sustained. The umbrella cloud dispersed towards east, with an upwind deposition over Kagoshima City of only few millimeters during the first 2 days. Ash began to fall on Miyazaki (i.e., $80 \mathrm{~km}$ downwind) by around 2 a.m. on 13 January, and on Tokyo (950 km downwind) by the early morning of 14 January. Although the explosive intensity decreased over the following days, ash was still deposited $200 \mathrm{~km}$ from the volcano until 19 January, defining a complex dispersal area with lobes towards the N, E, and S. From 20 January, the activity declined again in intensity, confining ash fall to a few localities close to Sakurajima. By 8:30 p.m. on 13 January, incandescence was observed on the flanks of the volcano, suggesting the onset of lava effusion. Lava erupted from multiple vents aligned along both the western and eastern fissures. Effusion ended in April 1914, although lava front instability, incandescence, and localized steaming were observed until April 1915. Sporadic explosions forming impulsive, low-level ash plumes and ejecting breadcrusted blocks occurred from craters along the two fissures until February 1914, with one vent periodically erupting until October 1915.

The impact of the eruption, although large, was strongly reduced by the spontaneous evacuation of some 22,000 inhabitants of the island before the eruption. While more than 4500 houses were destroyed by lava, pyroclastic flows, and ash, the 
M7.1 earthquake caused the total collapse of approximately 120 buildings in Kagoshima City. More than 2000 horses, oxen, and pigs were killed by the eruption, and agricultural sectors suffered severe damage. An economic loss of more than four million Japanese yens (JPY) was estimated (corresponding to about four billion JPY in current value) and was dominated by property damage.

\section{Comparison with the preceding eruptions}

Compared to the Taisho eruption, the Bunmei eruption had a longer total eruption duration (from 1471 to 1478). It was characterized by a complex eruptive sequence with repeated episodes of sustained but unsteady explosive activity followed by lava effusion from different fissure systems. Two major episodes of ash fall occurred in November 1471 and September 1475, but the most intense Plinian-type activity occurred on 29 September 1476. The 1476 event lasted for 7 days and was immediately followed by lava flows.

More reports of observations are available for the Anei eruption (1779-1782 AD) and reveal an onset around 11 a.m. on 9 November 1779 from the summit vent of Minamidake, followed $3 \mathrm{~h}$ later by the opening of a new vent forming a convective plume along a fissure on the south flank of the volcano. The explosive phase had a similar evolution as the Taisho eruption, reaching its climax after about $12 \mathrm{~h}$, and progressively decreased during the same day. The plume was dispersed by high-level winds to the east. The paroxysmal phase was then followed by emission of low-level plumes until 16 November. As with the Bunmei and Taisho eruptions, lava flow activity accompanied the end of the paroxysmal phase, and vents gradually migrated towards the sea, causing the formation of nine small islands. Explosive hydromagmatic activity was sporadically associated to these submarine vents, ejecting mud, sand, and ash that reached land. The eruption affected the island of Sakurajima within a radius of $8-10 \mathrm{~km}$ from the summit crater, claiming about 150 victims in the southern villages of the volcano and destroying more than 500 houses. Houses in the villages of Furusato and Arimura along the southern coast were completely burnt by the ejecta, possibly suggesting the occurrence of minor pyroclastic density currents and/or hot bombs.

Analysis of archived reports and data collected for these three eruptions thus suggests that all three had paroxysmal phases lasting for two or more days characterized by an initial waxing stage of some hours followed by a climactic subplinian to Plinian stage which lasted for at least $6 \mathrm{~h}$, and closed with a waning stage which passed into a days-toweeks-long activity of ash emission and generation of lowlevel plumes dispersed over smaller areas. The onset of lava flow effusion generally corresponded to the first phases of the waning stages of the Plinian phases. The main eruptive parameters for the three eruptions, as derived or critically revised by Todde et al. (2017), Todde (2016), and Cioni et al. (in prep), are summarized in Table 1.

\section{Hazard assessment}

Our hazard assessment is performed using the advection diffusion model Tephra2 (see Bonadonna et al. 2005; Bonadonna 2006; Connor and Connor 2006; Volentik et al. 2009; Biass et al. 2016b and references therein for more details of Tephra2 and its applications). We first inverted the deposit thicknesses to constrain eruption source parameters (ESP) for the probabilistic hazard assessment using TephraProb (Biass et al. 2016a).

\section{Numerical inversion}

The Bunmei, Anei, and Taisho tephra deposits characterized by Todde et al. (2017) and Todde (2016) were inverted using the Tephra2 optimization algorithm of Connor and Connor (2006) to constrain the empirical parameters required by Tephra2 (e.g., diffusion coefficient and fall-time threshold, see Bonadonna et al. 2005; Volentik et al. 2010; Biass et al. 2016a). Initial ranges of ESPs (e.g., plume height, erupted mass, total grain size distribution) used as inputs to the optimization algorithm are based on results of Todde (2016) and

Table 1 Summary of the eruption source parameters used for the Plinian phases of three most recent eruptions of Sakurajima volcano (Todde et al. 2017; Cioni et al., in prep)

\begin{tabular}{llll}
\hline Eruptive parameters & Bunmei & Anei & Taisho \\
\hline Volume $\left(\mathrm{km}^{3}\right)$ & $0.30 \pm 0.04$ & $0.18 \pm 0.04$ & $0.33 \pm 0.11$ \\
DRE volume $\left(\times 10^{7} \mathrm{~m}^{3}\right)$ & $8.10 \pm 2.50$ & $4.86 \pm 2.73$ & $8.83 \pm 3.26$ \\
Mass $\left(\times 10^{10} \mathrm{~kg}\right)$ & $20.3 \pm 6.2$ & $12.2 \pm 4.3$ & $21.6 \pm 7.2$ \\
Plume height $(\mathrm{km})$ & $17.3 \pm 1.7$ & - & $15.0 \pm 1.2$ \\
Peak MER $\left(\times 10^{7} \mathrm{~kg} \mathrm{~s}^{-1}\right)$ & $2.06 \pm 0.78$ & - & $3.60 \pm 1.20$ \\
TGSD Md $\Phi$ & -2.27 & -1.25 & -1.28 \\
TGSD $\sigma \Phi$ & 1.98 & 2.07 & 2.25 \\
\hline
\end{tabular}

When present, the uncertainty is expressed as $1 \sigma$ around the mean value. The range of tephra volumes represents the discrepancies between the exponential, power-law, and Weibull approaches (Pyle 1989; Fierstein and Nathenson 1992; Bonadonna and Houghton 2005; Bonadonna and Costa 2012). The DRE was fixed at $2500 \mathrm{~kg} \mathrm{~m}^{-3}$, and the deposit density was measured to be $676 \pm 189 \mathrm{~kg} \mathrm{~m}^{-3}$. The range of plume heights accounts for various methods to characterize clast dimensions (Bonadonna et al. 2013; Bagheri et al. 2015; Bagheri and Bonadonna 2016). The reported mass eruption rate (MER) is calculated with the method of Degruyter and Bonadonna (2012) and accounts for the uncertainty on the plume height. The total grainsize distribution was reconstructed with the Voroni technique (Bonadonna and Houghton 2005; Biass and Bonadonna 2014). Note that, although most observations of Todde et al. (2017) reveal bi- to tri-modal TGSDs, parameters reported here are those of Inman (1952) and are computed based on the assumption of a symmetrical distribution 
increased to cover the full range of VEI 4 eruptions (Table 2). Ranges of diffusion coefficient and fall-time threshold are based on Bonadonna et al. (2005). The mass distribution in the plume is described by a beta probability density functionbased on two-shape factors $\alpha$ and $\beta$ (Biass et al. 2016a). To constrain the mass distribution in the uppermost half of the plume, we constrain $\alpha=3$ and invert $\beta$ in the range $0.001-$ 3.000. The case $\alpha=\beta=3$ implies a symmetrical distribution of mass in the plume centered on the half of the plume height, whereas $\alpha>\beta$ results in a distribution of mass skewed towards the top of the plume.

Table 2 summarizes the optimum sets of ESPs best reproducing the tephra deposits from the three eruptions, and Fig. 2 displays the fit between observed and computed values of tephra accumulation and results in a satisfactory description of the field data by Tephra2. Although the computed tephra masses are generally lower than those obtained by Todde (2016), all masses are in the range of $10^{10}-10^{11} \mathrm{~kg}$. The total grain size distribution (TGSD), assumed as a simple Gaussian distribution, results in $\mathrm{Md}_{\Phi}$ and $\sigma_{\Phi}$ values (i.e., median and sorting coefficients; Inman 1952) between -2.1 to -2.9 and 1.0 to 2.9 , respectively. This range overlaps with results obtained using field data and the Voronoi method which gives $\operatorname{Md}_{\Phi}$ and $\sigma_{\Phi}$ values of -1.2 to -2.5 and 2.0 to 2.4 (Bonadonna and Houghton 2005; Biass and Bonadonna 2014), but is generally coarser and with poorer sorting. Note that Todde (2016) reports a polymodality of all TGSDs, which cannot be resolved by Tephra2. The best $\beta$ is larger than 2.6 for all eruptions, implying a maximum of mass distribution in the plume slightly above the center of the plume.

\section{Tephra modeling}

The TephraProb toolbox (Biass et al. 2016a) was used for probabilistic hazard modeling. Here, we quantify the spatial distribution of probabilities to exceed thresholds of tephra accumulation given the occurrence of the eruption scenario.

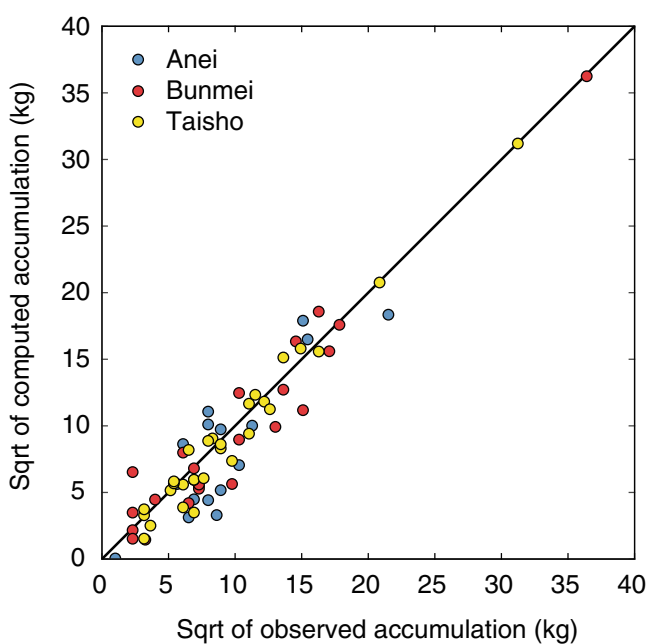

Fig. 2 Results of the optimization of the Anei, Bunmei, and Taisho deposits mapped by Todde (2016) with the Tephra2 model (Connor and Connor 2006). Colored dots represent the relationship between observed and computed tephra accumulations for the best results shown in Table 1 for each of the three eruptions. The solid black line represents a theoretical perfect reproducibility of the deposit by the model

\section{General modeling framework}

Wind conditions were inferred for the period 2000-2015 from the European Centre for Medium-Range Weather Forecasts (ECMWF) Era-Interim Reanalysis dataset, which provides four daily datasets at 37 pressure levels (Dee et al. 2011). Figure 3 shows the probability of the wind to blow in a given direction at a specific velocity at altitudes of 5,10 , and $15 \mathrm{~km}$ asl for (i) the entire 2000-2015 period; (ii) months of the winter, spring, and fall seasons; and (iii) the summer months (i.e., July-September), revealing that summer months are characterized by lower wind velocities and a S-SW component at low altitudes. Our analysis did not reveal any yearly variability potentially reflecting an influence of El Niño/La Niña phenomena. All calculations were performed on the Baobab cluster of the University of Geneva on a 1-km spaced grid using a WGS84 UTM map projection.
Table 2 Input ranges to the optimization, best values of ESPs, and empirical parameters for Tephra2

\begin{tabular}{|c|c|c|c|c|c|}
\hline & \multicolumn{2}{|c|}{ Optimization range } & \multicolumn{3}{|c|}{ Optimization results } \\
\hline & Min. & Max. & Bunmei & Anei & Taisho \\
\hline Plume height (km asl) & 10,000 & 20,000 & 16,131 & 14,690 & 10,353 \\
\hline Tephra mass $\left(\times 10^{10}\right)$ & 1 & 100 & 12.8 & 3.6 & 6.7 \\
\hline $\operatorname{Md} \Phi$ & -3 & -1 & -2.9 & -3.0 & -2.1 \\
\hline$\sigma \Phi$ & 1 & 3 & 2.5 & 1.0 & 3.0 \\
\hline Diffusion coefficient $\left(\mathrm{m} / \mathrm{s}^{2}\right)$ & 0.001 & 10,000 & 2409 & 5809 & 4385 \\
\hline Fall-time threshold (s) & 0.001 & 10,000 & 3012 & 1712 & 2437 \\
\hline$\alpha$ & 3 & 3 & 3 & 3 & 3 \\
\hline$\beta$ & 0.001 & 3 & 3.0 & 2.6 & 2.9 \\
\hline
\end{tabular}


Fig. 3 Wind conditions for the period 2000-2015 above Sakurajima volcano as inferred from the ERA-Interim dataset (Dee et al. 2011) for three altitude levels. The middle and the right column illustrate the influence of seasonality on wind patterns. Roses show the probability of the wind to blow in a given direction (i.e., provenance +180 )
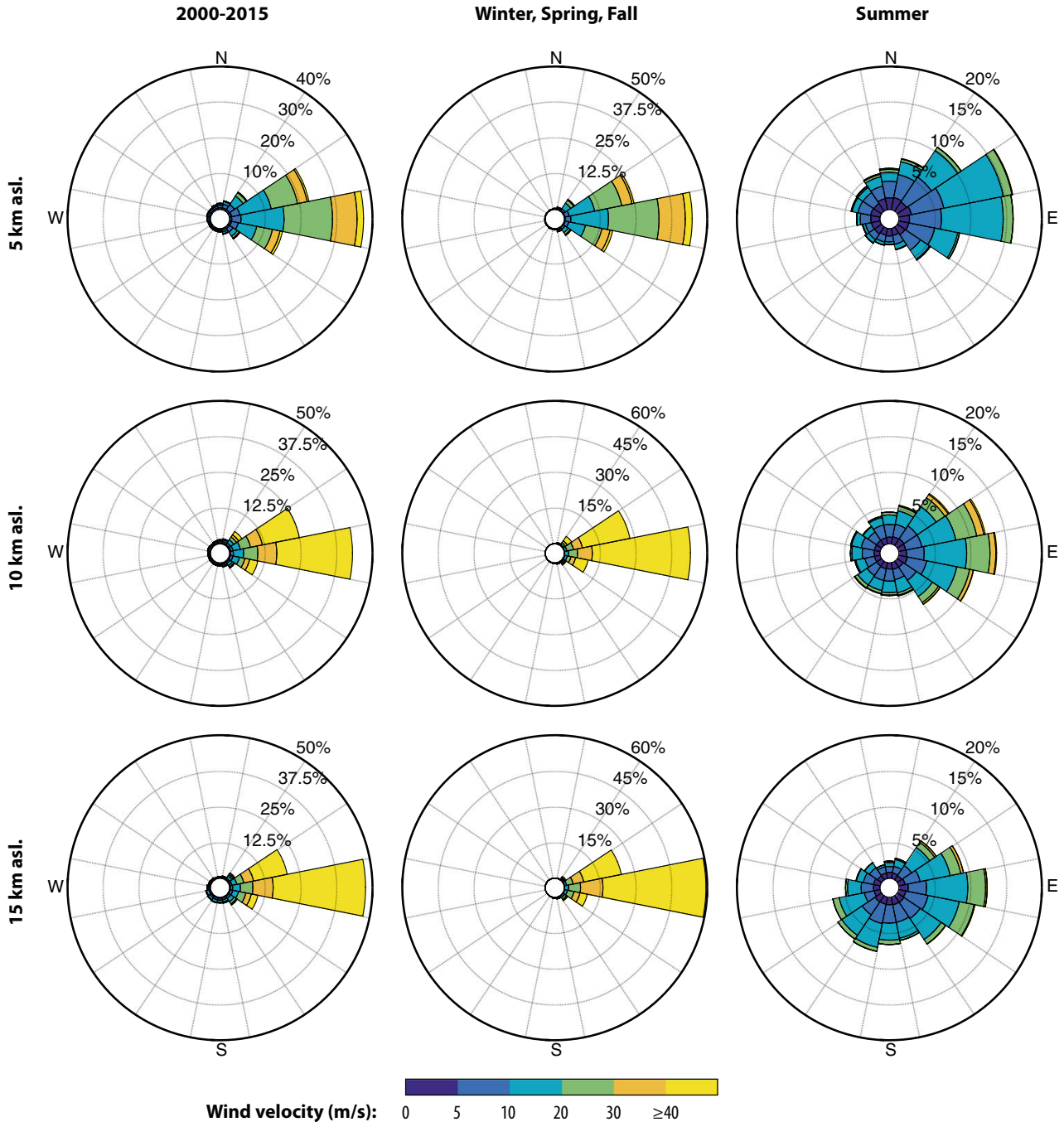

Wind velocity $(\mathrm{m} / \mathrm{s})$

\section{Eruption scenarios}

Eruption scenarios are defined by ranges of critical ESPs such as plume height, erupted mass, mass eruption rate (MER), eruption duration, and TGSD to frame eruption styles (e.g., Macedonio et al. 2008), intensities (e.g., Scaini et al. 2012), or magnitudes (e.g., Biass and Bonadonna 2013). Historical reports for Sakurajima highlight the multi-stage nature of eruptions (Yasui et al. 2013), including an intense, hours-long sustained phase. Historical accounts for the Taisho eruption suggest that the sustained, convective phase comprised an opening stage, a waxing stage leading to a climax a few hours after the eruption onset, and a waning period lasting for hours to days. Additional field evidence suggests shifts in plume regimes from strong to weak (Todde et al. 2017). Field and historical data confirm the predominance of fallout deposits related to the subplinian phase with respect to subsequent phases of long-lasting ash emissions. For this reason, we choose to focus our eruption scenarios on the climatic stage of the subplinian phase only.
Because multi-stage eruption dynamics are difficult to model, we adopt an alternative approach to describe scenarios associated with shifts in eruption intensities. First, we define a range of total mass of tephra identified from the application of empirical and analytical models to the Bunmei, Anei, and Taisho deposits. Second, based on historical reports, we consider two distinct scenarios lasting for 1-6 and 6-48 h reflecting the durations of the climatic stage and the entire sustained phases, respectively (Omori 1914; Kotô 1916). Third, we scale the MER (and thus the plume height) to erupt the fixed mass over these durations, assuming quasi-steady ESPs over the entire duration of the eruption.

The approach of Black et al. (2016) is used to scale plume height and MER to produce an equal mass over the different eruption durations. We first calculated a range of MER for each eruption scenario considering a steady emission of mass as summarized in Table 3 for the durations shown in Table 4, where the maximum MER is the ratio between the maximum mass and the minimum duration. Using the method of Degruyter and Bonadonna (2012), we infer plume heights 
Table 3 Eruption source parameters for a VEI 4 eruption based on historical eruptions of Sakurajima

\begin{tabular}{lll}
\hline ESP & Min. & Max. \\
\hline Erupted mass $\left(\times 10^{10} \mathrm{~kg}\right)$ & 5.3 & 53 \\
$\operatorname{Md}_{\Phi}$ & -2.5 & -1 \\
$\sigma_{\Phi}$ & 1.8 & 2.5 \\
Aggregation coefficient $(\%)$ & 20 & 80 \\
TEPHRA 2 parameters & Value & \\
Plume model & Beta & \\
$\alpha$ & 3 & \\
$\beta$ & 2.9 & \\
Fall-time threshold $(\mathrm{s})$ & 4000 & \\
Diffusion coefficient $\left(\mathrm{m}^{2} / \mathrm{s}\right)$ & 2500 & \\
\hline
\end{tabular}

Empirical parameters for Tephra2 obtained from inversion modeling are also specified

based on the calculated MER. The minimum plume height is calculated based on the minimum MER and a wind speed of $40 \mathrm{~m} / \mathrm{s}$, and the maximum plume height is based on the maximum MER and a wind speed of $10 \mathrm{~m} / \mathrm{s}$, where wind speed thresholds were set using the range of mean wind velocities for plume heights considered here (Fig. 3). Using this approach, the 1-6- and the 6-48-h scenarios are associated with plume heights of 7-24 and 4.5-10 km asl, respectively. These values agree with the range of plume heights obtained by Todde (2016) based on field measurements (i.e., $15-18 \mathrm{~km}$ asl) and reports of Omori (1914) and Kotô (1916) (i.e., variable between 3 and $18 \mathrm{~km}$ asl during the main explosive phase). While the first scenario accounts for a Plinian phase characterized by a climactic stage with a discharge rate significantly higher than the preceding and following stages (and during which most of the mass is ejected), the second scenario is a proxy for eruptions characterized by a less intense climactic stage.

While not attempting to reproduce the fallout patterns of a multi-stage eruption, this approach illustrates the variability in hazard patterns when a fixed tephra mass is erupted over various durations. We argue that the quantification of such a variability is of importance for emergency management in order to identify and plan crisis responses over different time scales.

Table 4 Time-averaged MER based on ESPs in Table 3 and corresponding plume heights for 1-6- and 6-48-h eruption scenarios

\begin{tabular}{|c|c|c|c|c|c|c|}
\hline & \multicolumn{2}{|c|}{ Duration (h) } & \multicolumn{2}{|c|}{$\operatorname{MER}(\mathrm{kg} / \mathrm{s})$} & \multicolumn{2}{|c|}{ Plume height (km asl) } \\
\hline & Min. & Max. & Min. & Max. & Min. & Max. \\
\hline Scenario 1 & 1 & 6 & $1.8 \times 10^{6}$ & $1.4 \times 10^{8}$ & 7 & 24 \\
\hline Scenario 2 & 6 & 48 & $3.1 \times 10^{5}$ & $2.6 \times 10^{6}$ & 4.5 & 10 \\
\hline
\end{tabular}

\section{Probabilistic hazard modeling}

The eruption scenarios are modeled using both short- and long-lasting Eruption Range Scenario (ERS) strategies (Bonadonna 2006; Biass et al. 2014b, 2016a), which compile probability maps based on the statistical distribution of ESPs and wind conditions. Following Biass et al. (2016a), a scenario is called long-lasting when the duration exceeds the temporal resolution of the atmospheric data (i.e., $6 \mathrm{~h}$ for the EraInterim dataset).

Each scenario simulates 5000 eruptions with varying eruption and wind conditions. Following Biass et al. (2014b), eruption start date and duration are sampled first from a uniform distribution. The eruption duration is split into 6-h-long periods, for which wind conditions are retrieved and plume heights are sampled on a logarithmic scale within the ranges specified in Table 4. Plume heights, eruption durations, and wind conditions are used to calculate a total mass of tephra for each eruption using the MER method of Degruyter and Bonadonna (2012). If the obtained mass falls within the interval specified in Table 3, the simulation is assumed valid; otherwise, the sampling process is restarted until 5000 valid eruptions are resolved. Figure 4 summarizes the distributions of ESPs obtained from the stochastic sampling. Plume heights for the 1-6-h scenario follow a lognormal distribution with a mode around $12 \mathrm{~km}$ asl and few solutions for plume heights $>18 \mathrm{~km}$ asl. In contrast, the distribution of plume heights for the 6-48-h scenario is uniform. MERs for both scenarios are clustered around central values of modes, these being $\sim 10^{6.5}$ and $10^{7.5} \mathrm{~kg} / \mathrm{s}$ for the 1-6- and 6-48-h scenarios, respectively. Although the distributions of erupted masses result in symmetrical distributions that are counter-intuitive compared to typical power-law frequency-magnitude relationships (e.g., Sandri et al. 2016; Sheldrake and Caricchi 2016), our aim here is to validate realistic eruption conditions for a specific scenario validated from detailed field observations and physical models, rather than satisfying statistical trends required for long-term or large-scale/multi-source hazard analyses.

The TGSD is defined as a Gaussian distribution (in $\Phi$ units; $-\log _{2}($ diameter $\left.[\mathrm{mm}])\right)$ and sampled based on the median and sorting coefficients defined in Table 3 . The resulting distribution is modified to account for aggregation process based on observations of Bonadonna et al. (2002, 2011). An aggregation coefficient is sampled and used to remove a given fraction of fine material $\geq 4 \Phi$, which is equally redistributed in classes $-1 \Phi$ to $3 \Phi$. The TGSD is assumed constant for the duration of the simulated eruption.

The hazard is expressed as the exceedance probabilities $P$ of a ground tephra accumulation $M\left(\mathrm{~kg} / \mathrm{m}^{2}\right)$ to exceed an accumulation threshold $M_{T}\left(\mathrm{~kg} / \mathrm{m}^{2}\right)$ at geographical coordinates $x, y$ at a time $t$ after the eruption onset:

$P\left[M(x, y, t) \geq M_{T} \mid\right.$ eruption scenario $]$ 
Fig. 4 Eruption source parameters obtained from the application of the method of Biass et al. (2014) for the eruption scenarios defined in Tables 3 and 4. Distributions of a plume heights and $\mathbf{b}$ MER contain the data for $6 \mathrm{~h}$ long periods (i.e., an eruption lasting for $15 \mathrm{~h}$ is assigned three values of plume heights; see text for details). Distributions of $\mathbf{c}$ durations and $\mathbf{d}$ masses used to describe the eruption
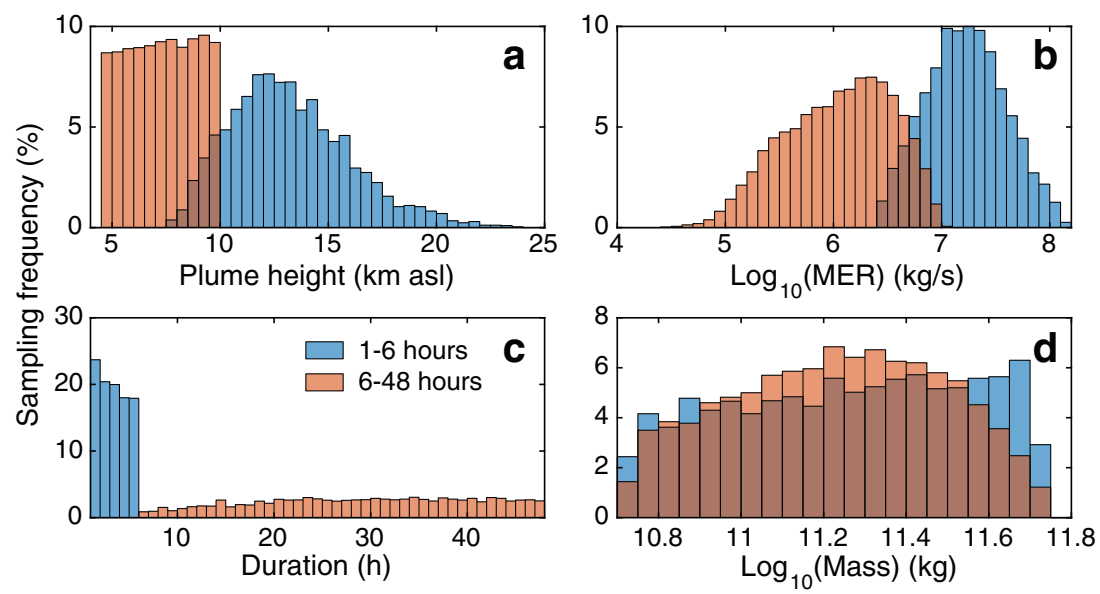

Probabilities are conditional to the occurrence of the associated eruption scenario.

\section{Results}

Results are compiled as probability maps (Fig. 5), probabilistic isomass maps (Fig. 6), and hazard curves (Fig. 7), which consider probabilities of tephra fall accumulation at selected sites over the entire duration of the eruption scenario. Probability maps (Fig. 5) show the spatial distribution of probabilities that exceed tephra accumulations of 1 and $100 \mathrm{~kg} / \mathrm{m}^{2}$, respectively. These represent important thresholds for agriculture, critical infrastructures, and physical impacts on buildings and transportation (Blong 1984; Wilson et al. 2012a; Wilson et al. 2012b; Jenkins et al. 2014a; Hampton et al. 2015; Hayes et al. 2015; Blake et al. 2016). Figure 6 shows the tephra accumulation for fixed exceedance probabilities of 25 and $75 \%$, and Fig. 7 presents the probability of exceeding any tephra accumulation for critical locations shown in Fig. 1. City halls were chosen as the representative location for the center of the most exposed municipalities, and harbors, railway stations, and airports were selected due to their importance in the transportation network.

In agreement with Fig. 3, all modeled scenarios are dominated by eastward tephra dispersal, but lower plume heights are affected by a southeast component (e.g., 6-48-h scenario: Figs. 3, 5, and 6). The Sakurajima Ferry Port (upwind, $6 \mathrm{~km}$ from the vent) and the Tarumizu City Hall (crosswind, $11 \mathrm{~km}$ from the vent) are the two most exposed infrastructures amongst those selected in our study. For accumulations $<10 \mathrm{~kg} / \mathrm{m}^{2}$, these two locations are the only ones for which the 6-48-h scenario results in a higher hazard than the 1-6-h scenario (i.e., there is a $10 \%$ more likelihood of exceeding accumulations of $10 \mathrm{~kg} / \mathrm{m}^{2}$ for the 6-48-h scenario).

The Tarumizu City Hall, located $11 \mathrm{~km}$ downwind from the vent, is exposed to probabilities of accumulations of $1 \mathrm{~kg} /$ $\mathrm{m}^{2}>\sim 50 \%$. At the same distance upwind from the vent (e.g., Kagoshima Central Station), probabilities decrease to $>30 \%$ (Table 5). The Kagoshima Airport and the Kokubu Station (at 25 and $21 \mathrm{~km}$ from the vent, respectively) are both located north from the volcano, with the latter being downwind. This difference relative to the dominant winds results in significantly different probabilities of accumulations of 1 and $10 \mathrm{~kg} / \mathrm{m}^{2}$ (Table 5). For an accumulation of $1 \mathrm{~kg} / \mathrm{m}^{2}$, an increasing eruption duration increases the probability for the Kokubu Station (i.e., 23 to $26 \%$ ) but decreases the probability for the Kagoshima Airport (17 to 16\%). Because a threshold of $1 \mathrm{~kg} / \mathrm{m}^{2}$ is often considered critical for ground operations at airports (Blong 1984; Guffanti et al. 2009; Volentik and Houghton 2015), our results suggest that the hazard to the Kagoshima Airport decreases with increasing eruption duration and decreasing intensity. Finally, the Miyakonojo Central Station is both the most distal (43 km from the vent) and the closest to the dominant downwind dispersal, and has a $\sim 10 \%$ probability of exceeding an accumulation of $1 \mathrm{~kg} / \mathrm{m}^{2}$.

Distributions of probabilities (Fig. 7, Table 5) suggest that accumulation patterns are a function of geographical location (i.e., distance, location around the vent, and wind direction) and the eruption duration, both defining a critical tephra accumulation below which long-lasting eruptions result in higher probabilities than short-lasting eruptions (and above which the opposite is true). For Tarumizu City Hall and Sakurajima Ferry Port, these thresholds are $\sim 100$ and $\sim 20 \mathrm{~kg} / \mathrm{m}^{2}$, respectively. This is a direct consequence of long-lasting eruptions being characterized by a lower MER and affected by more variable wind patterns.

Figure 5e, fillustrates how summer months result in a more northwest-oriented sedimentation of tephra compared to other seasons, thus decreasing the hazard to infrastructure located towards the south (e.g., Tarumizu City Hall) and east (Miyakonojo Central Station; Fig. 7). Note that, although this northward dispersal is not clearly reflected in Fig. 3, this is only the result of an artifact of using a central value (i.e., the mean) to describe a scattered population. A closer look at the 

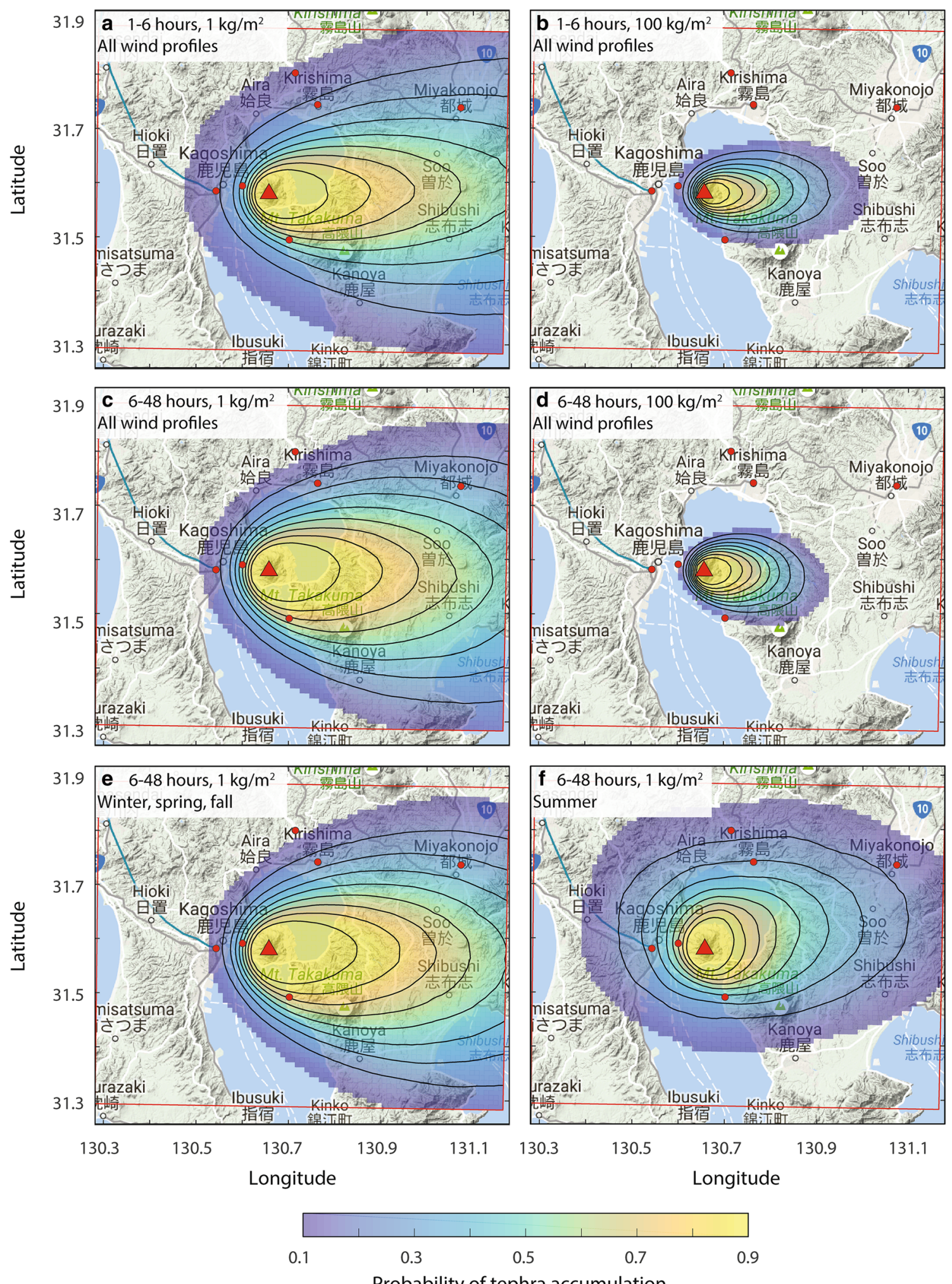

Probability of tephra accumulation

Fig. 5 Probability maps to exceed tephra accumulations of $1 \mathrm{~kg} / \mathrm{m}^{2}$ (a, c, e, f) and $100 \mathrm{~kg} / \mathrm{m}^{2}(\mathbf{b}, \mathbf{d})$ for the 1-6- and the 6-48-h scenarios. The seasonality effect is illustrated by the $6-48$-h scenario for a probability to exceed an accumulation of $1 \mathrm{~kg} / \mathrm{m}^{2}$ considering $\mathbf{c}$ all wind profiles; $\mathbf{e}$ wind profiles for winter, spring, and fall; and $\mathbf{f}$ wind profiles for the months of July, August, and September. Probabilities are expressed between 0 and 1 and are conditional on the occurrence of the respective eruption scenario. The red triangle locates the Showa crater, the red dots locate critical infrastructures (Fig. 1), and the red frame is the extent of the computation grid. Black contours range from 0.2 to 0.9 with increments of 0.1. Map background is Google Map (Map data (02017 Google) 

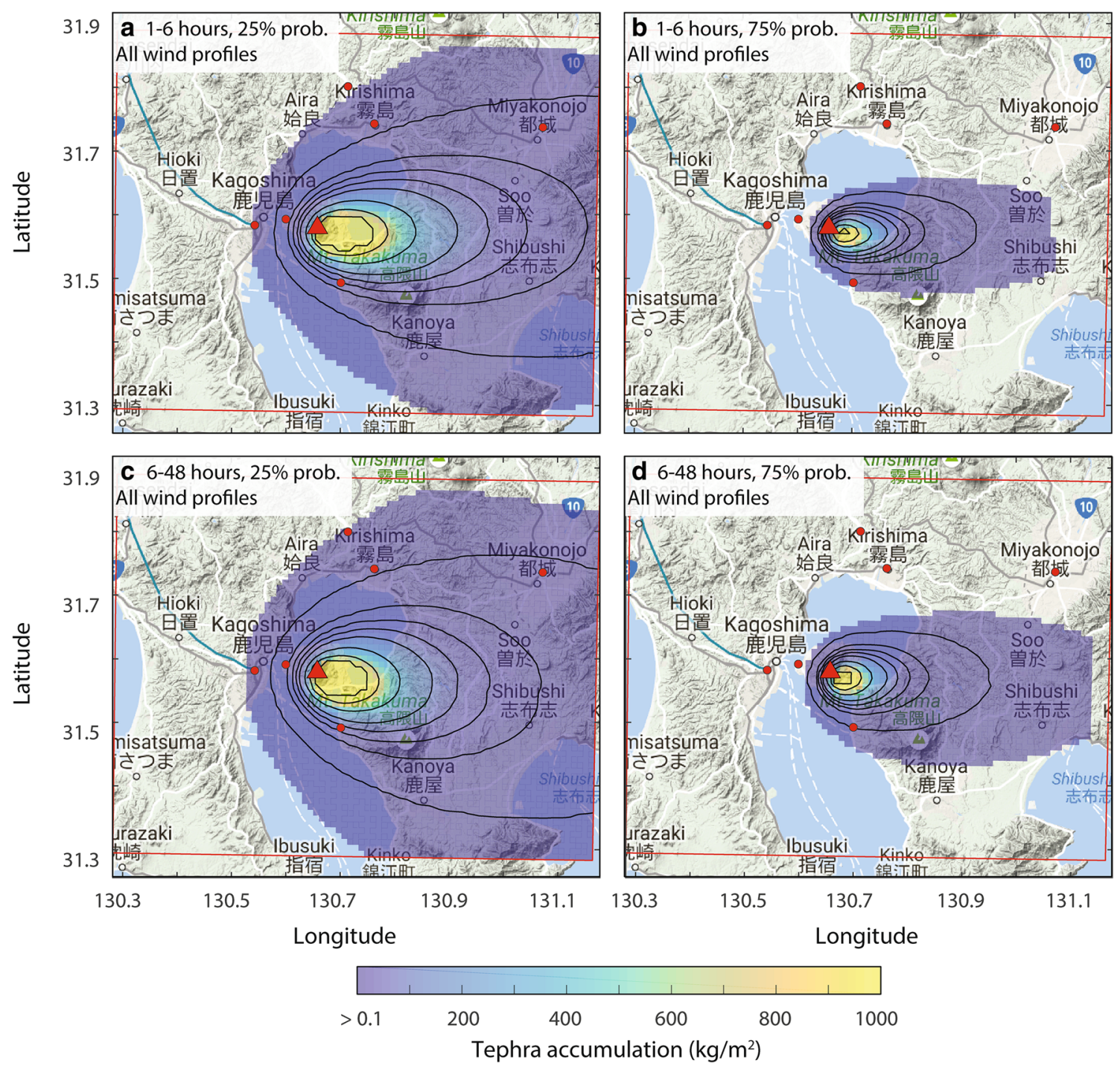

Fig. 6 Probabilistic isomass maps showing the tephra accumulations occurring at a probability of $25 \%$ (left column) and $75 \%$ (right column) for the 1-6- and the 6-48-h eruption scenarios (first and second rows, respectively). These accumulations are conditional on the occurrence of

wind data reveals that summer months are less clustered around a single trend, especially at altitudes $<5 \mathrm{~km}$ asl.

\section{Exposure analysis}

We conducted a basic exposure analysis serving as a first step towards a pre-event impact/risk assessment. Our approach is based on the post-event impact assessment of the 2011 eruption of Shinmoedake of Magill et al. (2013) and focuses on the exposure of (i) road, railroad, and electricity networks; (ii) the built environment and agricultural land; and (iii) human population. We present an exposure analysis using the 6-48-h eruption scenario as a reference for the hazard. The exposure is calculated as the geographic intersection between exposed the respective eruption scenario. Symbols follow Fig. 4. Black contours represent accumulations of 1, 10, 25, 50, 100,300, 700, and $1000 \mathrm{~kg} / \mathrm{m}^{2}$. Map background is Google Map (Map data @2017 Google)

infrastructures and probabilistic isomass maps (Fig. 6). The uncertainty on the hazard is arbitrarily given by the probabilistic isomass maps computed for exceedance probabilities of 25\% (Fig. 6a) and 75\% (Fig. 6b).

\section{Methodology}

GIS setup

The exposure analysis was developed within QGis (QGIS Development Team 2016). All datasets were projected on a WGS84 UTM Zone 52R coordinate reference.

Administrative boundaries In Japan, administrative centers below the level of prefectures are named and identified with 

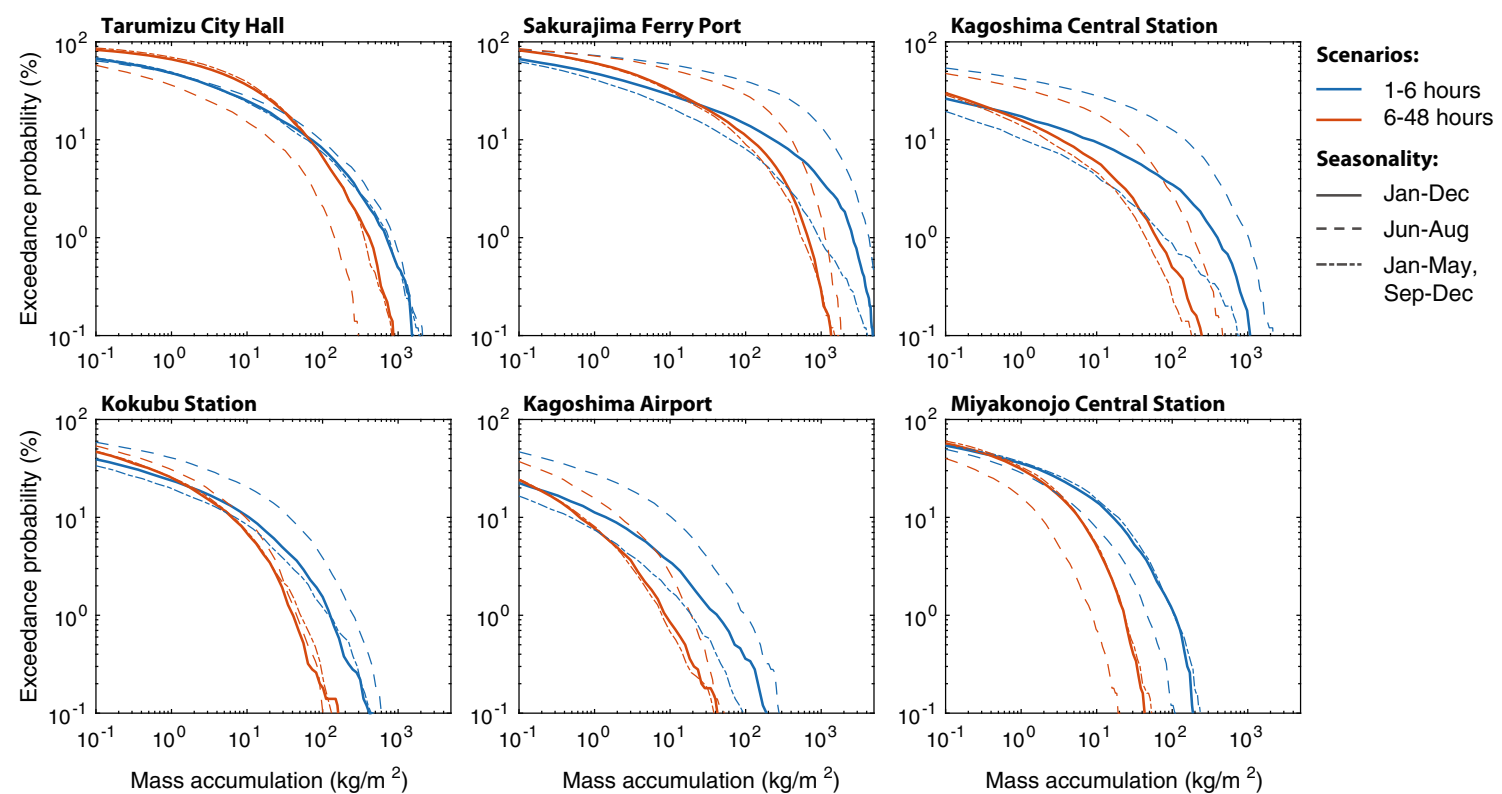

Fig. 7 Hazard curves for the critical infrastructures shown in Figs. 1, 4, and 5. Line colors represent scenarios at different durations. Line styles represent the months of the year used for the stochastic sampling of

atmospheric data within the period 2000-2015. Mass accumulations describe the total accumulation from the entire duration of the eruptions

the appendices - Shi (i.e., containing more than 50,000 people; e.g., Kagoshima-Shi) or -Cho (i.e., for less than 50,000 people; e.g., Osaki-Cho). Here, we use the generic translation municipality to describe the administrative level below prefectures regardless of the population.

Our study area is part of the Southern Kyushu region, comprising 17 municipalities across the prefectures of Kagoshima and Miyazaki (Fig. 1). Administrative boundaries and population estimates were obtained using the 2014 census of the Geospatial Information Authority of Japan, where demographic estimates are aggregated per municipality (GSI 2016).

Transportation network The transportation network was obtained from OpenStreetMap (OSM; OSM 2016) through the OSM QGis plugin (Fig. 8a), from which we retrieved the road network, the railroad network, and the location of airports. In each case, the original OSM classification was preserved, but all roads below the secondary class were aggregated in one generic class in Fig. 8a (i.e., tertiary, residential, unclassified, and service classes).

Land use A land use map was generated from the supervised classification of a multi-spectral Landsat 8 image (scene LC81120382016304LGN00 obtained on 31 October 2016). The classification was done in ENVI using all bands at a resolution of $30 \mathrm{~m}$ and optimizing results with high-resolution imagery from Google Earth to identify areas of built environment and agricultural land. This approach is similar to the previous works of Bonne et al. (2008), Favalli et al. (2012), or Magill et al. (2013). Although no quantitative validation

Table 5 Summary of the hazard on critical infrastructures for both scenarios (see Fig. 7)

\begin{tabular}{|c|c|c|c|c|c|c|c|c|}
\hline \multirow[b]{3}{*}{ Location } & \multirow[b]{3}{*}{ Distance $(\mathrm{km})$} & \multirow[b]{3}{*}{ Sector } & \multicolumn{6}{|c|}{ Exceedance probability $(\%)$} \\
\hline & & & \multicolumn{3}{|c|}{ 1-6-h scenario } & \multicolumn{3}{|c|}{ 6-48-h scenario } \\
\hline & & & $1 \mathrm{~kg} / \mathrm{m}^{2}$ & $10 \mathrm{~kg} / \mathrm{m}^{2}$ & $100 \mathrm{~kg} / \mathrm{m}^{2}$ & $1 \mathrm{~kg} / \mathrm{m}^{2}$ & $10 \mathrm{~kg} / \mathrm{m}^{2}$ & $100 \mathrm{~kg} / \mathrm{m}^{2}$ \\
\hline Sakurajima Ferry Port & 5.7 & $\mathrm{~W}$ & 48.5 & 23.8 & 8.5 & 66.1 & 34.3 & 6.3 \\
\hline Tarumizu City Hall & 10.5 & $\mathrm{~S}$ & 48.3 & 28.1 & 15.1 & 61.4 & 30.9 & 11.5 \\
\hline Kagoshima Central Station & 10.9 & W & 36.5 & 13.6 & 1.3 & 29.8 & 5.4 & $<0.01$ \\
\hline Kokubu Station & 20.7 & $\mathrm{~N}$ & 22.9 & 10.1 & 1.5 & 26.0 & 6.5 & 0.2 \\
\hline Kagoshima Airport & 25.1 & $\mathrm{~N}$ & 17.3 & 9.7 & 3.5 & 16.0 & 6.4 & 0.5 \\
\hline Miyakonojo Central Station & 43.1 & $\mathrm{NE}$ & 11.2 & 3.4 & 0.4 & 8.4 & 0.9 & 0.0 \\
\hline
\end{tabular}


Fig. 8 Exposure of a the transportation network and $\mathbf{b}$ the land use and the electricity network. The road network, railroad network, and power lines are from OpenStreetMap. The land use map was obtained by the supervised classification of a Landsat 8 image. Black contours show the $1-, 10-$, and $100-\mathrm{kg} / \mathrm{m}^{2}$ tephra isomass for the $6-48-\mathrm{h}$ scenario for exceedance probabilities of $25 \%$ (solid lines) and $75 \%$ (dashed lines). White squares are cities labeled in Fig. 1. The map uses a UTM Zone 52N projection. Map coordinates are in kilometers

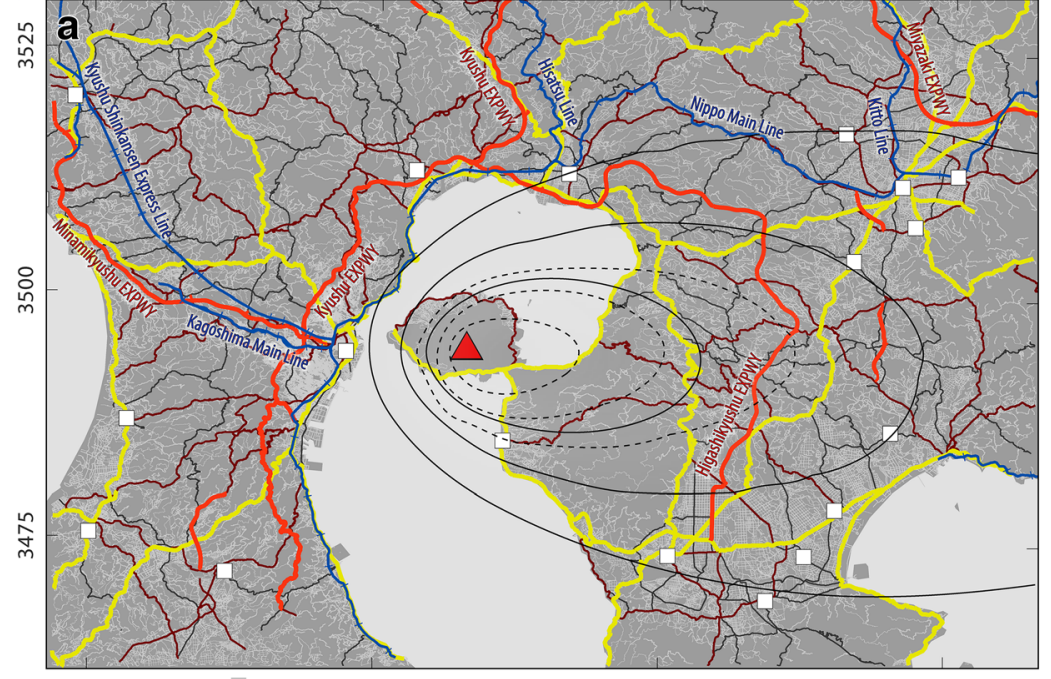

Road network

— Motorway

- Trunk

- Primary

Other

Rail network

— Tracks

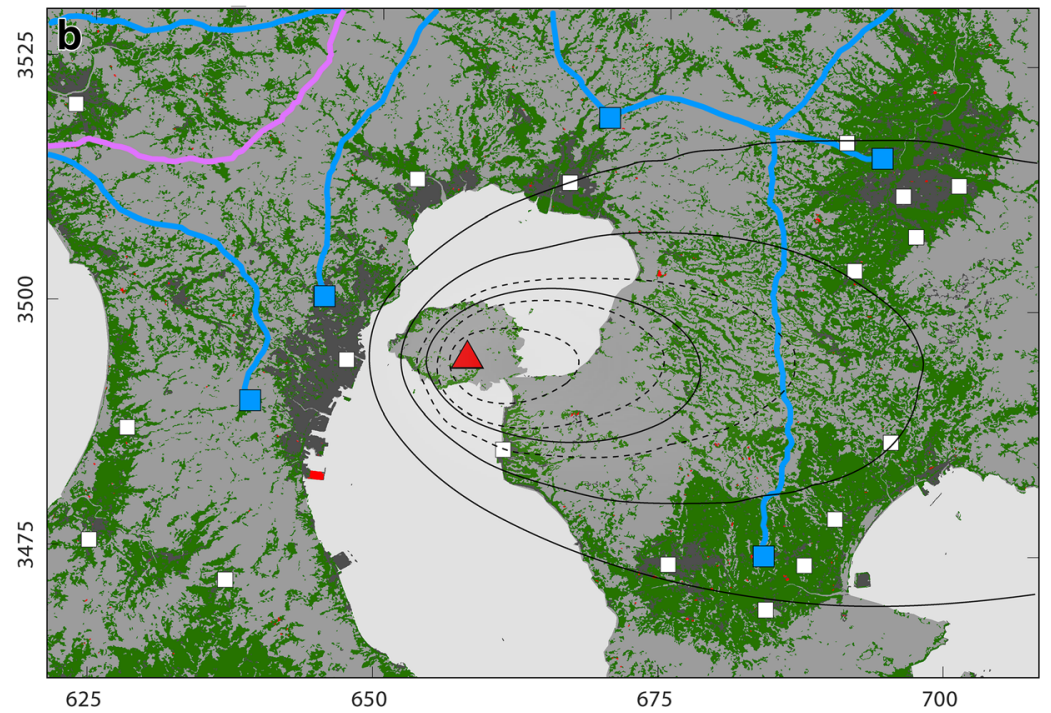

Power network

$220 \mathrm{kV}$ station $220 \mathrm{kV}$ lines $500 \mathrm{kV}$ Solar panels Landuse Built Agricultural was performed, visual inspection of results against Google Earth and incremental refining of reference zones resulted in a coherent classification of the classes of interest (Fig. 8b).

Urban areas in Japan are defined as zones "... having 50,000 or more inhabitants with $\geq 60 \%$ of the houses located in the main built-up areas and $\geq 60 \%$ or more of the population engaged in manufacturing, trade or other urban type of business" (Table 7 in United Nations Statistics Division 2005). Here, rather than identifying urban areas stricto sensu, our supervised classification defines the built environment based on reference zones spanning agglomerations of any size (Fig. 8b). Agricultural land resulting from our classification does not differentiate between pastoral and horticultural areas. Additional classes such as shrubs and forest were defined during the supervised classification to avoid the classification of all vegetation as agriculture.

Electricity network A partial dataset of the power network was obtained from the digitalization of the national 1:50,000 topographic map provided by the Geospatial Information Authority of Japan (GSI) (Fig. 8b) and contains parts of the 500- and 220-kV network. A comparison of our dataset with the Kyushu Electric Power Company map published in Magill et al. (2013) suggests that neither dataset is complete; the exposure of the electricity network assessed here is therefore a minimum. Additionally, the classification of the Landsat image was also used to assess the location and size of solar panels,

\section{Impact scores}

To build a framework for comparison, a simple qualitative ranking of municipalities was carried out in terms of exposure, hazard, and potential impacts based on basic indicators. Indicators for the exposure include (i) the total population, (ii) the built area, (iii) the agricultural area, and (iv) the total length of the road network. Note that the population is relative to the total area of the municipality, whereas all other indicators are relative to the area included in the extent of the study 
area. For this reason, ranks of municipalities at the edge of the study area should be critically interpreted.

For any given municipality, each separate indicator is normalized to the sum over all municipalities and all indicators are summed to obtain an exposure score. Scores are then ranked in descending order, where the highest score is assigned a rank of 1 . The hazard score is the ratio of the tephra mass occurring within a municipality with a probability of $25 \%$ normalized over the total mass in all municipalities and ranked in a similar way to the exposure. The impact score is the product of the exposure and hazard scores.

\section{Cleanup costs}

The cleanup of tephra is an effective measure to mitigate impacts, but such operations can be challenging, expensive, and time consuming (Blong 1984; Sword-Daniels et al. 2014; Hayes et al. 2015; Hayes et al. 2017). For the 2011 Shinmoedake eruption, Magill et al. (2013) estimated a cost of cleanup operations to the Miyazaki municipality of $23 \mathrm{JPY}$ per $\mathrm{kg}$ of tephra in urban areas and $17 \mathrm{JPY}$ per $\mathrm{kg}$ (or 50,300 JPY per km) on the road network. Because the Miyazaki prefecture is a neighbor to Kagoshima and is included in our study area, we chose the cleanup costs of Magill et al. (2013) over the tentative general model of Hayes et al. (2015) or the detailed model of Hayes et al. (2017) for cleanup costs in Auckland.

Two first-order estimates of cleanup costs are made here. First, we assess the cleanup cost of the road network based on the total length of the road network impacted by accumulations $\geq 1 \mathrm{~kg} / \mathrm{m}^{2}$. Note that the cleanup cost per length is preferred over the cleanup cost per mass because of the uncertainty on road width. Second, we estimate the cleanup cost in urban areas based on the mass of tephra obtained as a combination of the probabilistic isomass maps and the area of urban zones obtained from our land use classification. A range of cost is given based on the hazard occurring at probabilities of $75 \%$ (lower bound) and 25\% (higher bound). Monetary values are based on the estimates of Magill et al. (2013) in JPY and converted to US dollars (USD) using a 2016 rate (i.e., 1 $\mathrm{JPY}=0.00884$ USD as of December 2016).

\section{Results}

\section{Transportation network}

Road network Impacts of tephra fallout on roads include a loss of function varying from a reduced visibility, loss of traction, and coverage of road markings (from $\sim 1 \mathrm{~kg} / \mathrm{m}^{2}$ ) to the obstruction of vehicles (above $\sim 10 \mathrm{~kg} / \mathrm{m}^{2}$ ) and the abrasion of road surfaces (Wilson et al. 2012b; Jenkins et al. 2015b; Blake et al. 2016). Cleanup actions require planning and prioritization as a function of the road characteristics (e.g., function, width, surface) (Hayes et al. 2015).
Four motorways cross the study area (Fig. 8a). The Kyushu expressway crosses Kyushu Island from north to south, the Minamikyushu expressway connects Yatsushiro to Kagoshima along the western coast of Kyushu Island, the Higashikyushu expressway connects the north of the island to Kirishima along the east shore of Kyushu, and the Miyazaki expressway links Miyazaki to the Higashikyushu expressway. Table 6 summarizes potential tephra accumulations over the road network, with 634 $4668 \mathrm{~km}$ of roads (i.e., exceedance probabilities of 75 and $25 \%$, respectively) affected by accumulations $\geq 1 \mathrm{~kg} / \mathrm{m}^{2}$. A distance of $132-1686 \mathrm{~km}$ of roads is affected by $\geq 10 \mathrm{~kg} / \mathrm{m}^{2}$ of tephra according to the same probabilities. Dominant eastward tephra accumulation patterns (Figs. 5 and 6) make sections of the Higashikyushu and the Miyazaki expressways the most exposed, with up to $100 \mathrm{~km}$ of motorways affected by accumulation $\geq 1 \mathrm{~kg} / \mathrm{m}^{2}$. Summer months increase the probability of fallouts over the eastern section of the Kyushu and the Western section of the Minamikyushu expressways.

Railroad network Functional impacts of tephra fallout on railroad networks include reduction of visibility and disruption of signals (above $\sim 1 \mathrm{~kg} / \mathrm{m}^{2}$ ) to the loss of traction leading to unsafe operations (from $\sim 10 \mathrm{~kg} / \mathrm{m}^{2}$ ). Physical impacts include abrasion and corrosion of components resulting in mechanical failures (Magill et al. 2013; Jenkins et al. 2015b).

Five railroad lines operated by the Kyushu Railway company are present around Sakurajima. Two main lines, the Kagoshima and the Nippo lines, connect Kagoshima to the north of the island via the west and the east shores of Kyushu, respectively. Two local lines serve as a second-order connection to the Nippo line, namely, the Hisatsu and Kitto lines that connect at the Kokubu and Miyakonojo stations, respectively (Figs. 1 and 8a). Finally, the Kyushu Shinkansen high-speed line connects Fukuoka to Kagoshima. Figures 5 and 6 and Table 6 suggest that major fallouts on railroad tracks are unlikely for the eruption scenario considered here, with a total railroad length of $56 \mathrm{~km}$ having a $25 \%$ probability of being affected by accumulations $\geq 1 \mathrm{~kg} / \mathrm{m}^{2}$ (Table 6). No portion of the railroad line is affected by higher exceedance probabilities nor higher tephra accumulations. Important hubs are exposed to tephra accumulation including the Kagoshima (11 km west of the vent), the Kokubu (21 km north of the vent), and the Miyakonojo (43 km northeast of the vent) central stations (Figs. 1 and 7, Table 5). Summer months increase the hazard to the Kagoshima, Nippo, and Shinkansen lines.

\section{Land use}

Built environment From a functional perspective, tephra fallout on the built environment requires cleanup actions starting from accumulations of $\sim 1 \mathrm{~kg} / \mathrm{m}^{2}$. Larger accumulations $\left(\geq 100 \mathrm{~kg} / \mathrm{m}^{2}\right)$ may prohibit habitation of buildings due to ash infiltration and threat of roof collapse (Jenkins et al. 2015b; Hayes et al. 2015). 
Table 6 Summary of exposed infrastructures (Fig. 8) to tephra accumulations of 1, 10, and $100 \mathrm{~kg} / \mathrm{m}^{2}$

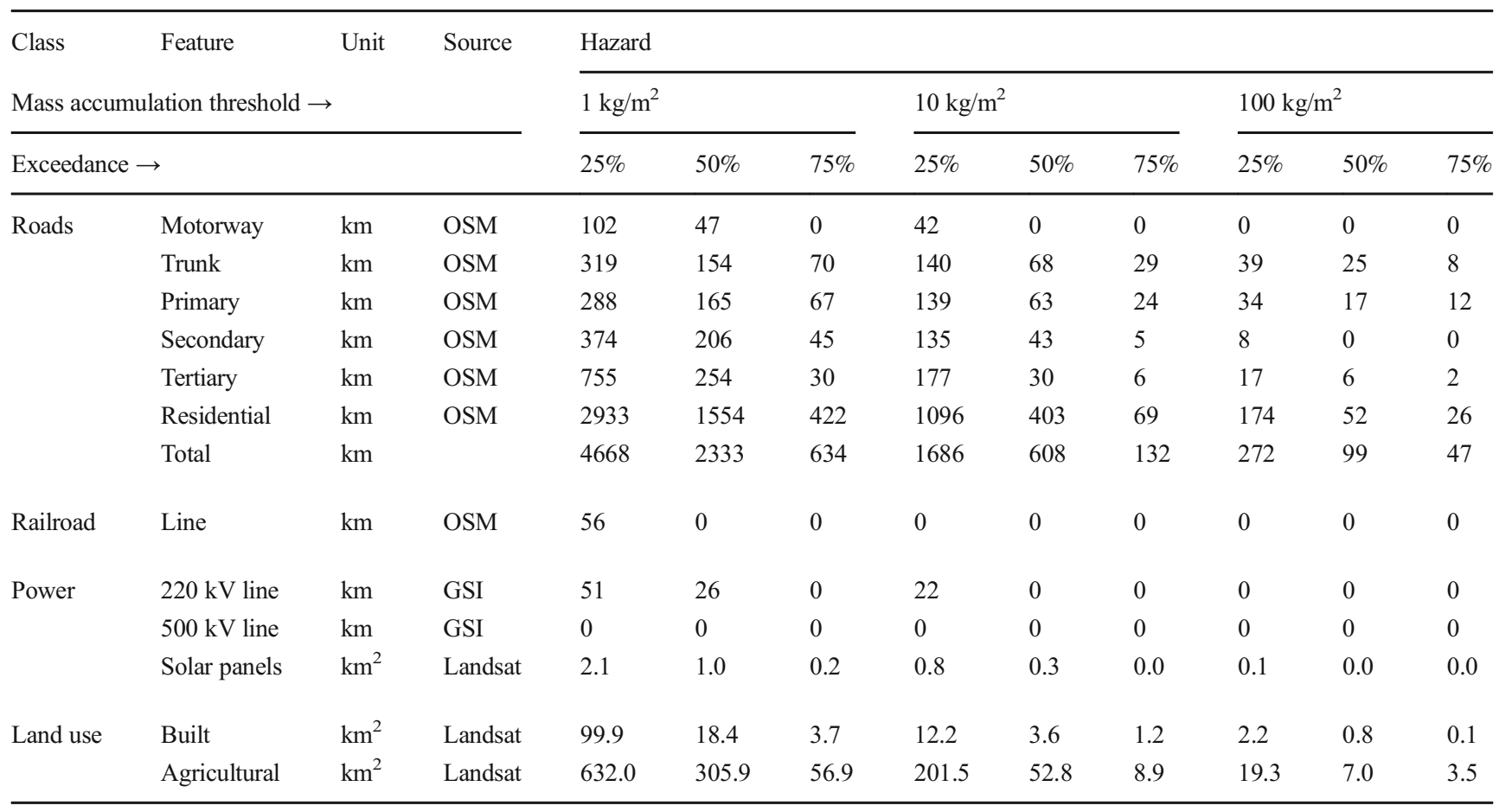

For each tephra accumulation, the exposure is expressed for exceedance probabilities of 25,50 , and $75 \%$. Note that in the case of an accumulation of $1 \mathrm{~kg} / \mathrm{m}^{2}$ and a probability of $25 \%$, contour lines extend outside of the calculation area (Figs. 5 and 6 ) and the reported exposure is a minimum value. See text for the detail of data sources

OSM OpenStreetMap, GSI Geospatial Information Authority of Japan

Non-structural damage ranges from corrosion and abrasion of gutters and overhangs $\left(\sim 1 \mathrm{~kg} / \mathrm{m}^{2}\right)$ to their potential destruction $\left(\geq 100 \mathrm{~kg} / \mathrm{m}^{2}\right)$ (Oze et al. 2014; Hampton et al. 2015). Structural damage, spanning partial to complete collapse of roofs and supporting structures, is highly dependent on the building type and ranges between 100 and $400 \mathrm{~kg} / \mathrm{m}^{2}$ (for roofs with timber support) to between 400 and $1400 \mathrm{~kg} / \mathrm{m}^{2}$ (for reinforced concrete roofs) (Pomonis et al. 1999; Spence et al. 2005; Jenkins et al. 2014a; Zuccaro et al. 2015). Additional impacts include the abrasion and corrosion of vehicles and machinery, clogging of air and water handling and filtration systems, and impacts on computers (Blong 1984; Wilson et al. 2012a; Wilson et al. 2012b; Marzocchi et al. 2012; Jenkins et al. 2015b).

Figure $8 \mathrm{~b}$ and Table 7 summarize the exposure of the built environment to tephra fallout. About $100 \mathrm{~km}^{2}$ of built environment has a $25 \%$ probability of suffering accumulations $\geq 1 \mathrm{~kg} /$ $\mathrm{m}^{2}$, which decreases to $\sim 4 \mathrm{~km}^{2}$ for a probability of $75 \%$. Up to $\sim 2 \mathrm{~km}^{2}$ has a $25 \%$ probability of exceeding $100 \mathrm{~kg} / \mathrm{m}^{2}$ of tephra. Figure 7 shows that heavier accumulation critical for roof collapse is mostly constrained to the Sakurajima peninsula and, to some extent, to the cities of Kagoshima and Tarumizu. In such a proximal context, larger-intensity eruptions (e.g., the 1-6-h scenario) result in higher probabilities of exceeding heavy tephra accumulations (Table 5) and season of the year has an important control on the hazard (Fig. 7).
Agricultural land Impacts on agricultural activities are a function of the interplay between a range of complex variables such as the style, duration and timing of the eruption, the type and size of farms, the climate, and preexisting vulnerabilities (e.g., Cronin et al. 2014; Jenkins et al. 2015b; Craig et al. 2016a; Stewart et al. 2016; Thompson et al. 2016; Craig et al. 2016b). Specifically, pastoral and horticultural farms are typically characterized by distinctive impacts. First, pastoral farms in temperate climates are relatively resilient to tephra accumulations of $1-10 \mathrm{~kg} / \mathrm{m}^{2}$, with principal impacts on cattle consisting of eye and skin irritation, tooth abrasion or gastrointestinal issues, and, potentially, poisoning depending on the concentration in toxic soluble elements (Ayris and Delmelle 2012; Magill et al. 2013; Jenkins et al. 2015b; Thompson et al. 2016). Along with shortage of food and water, these impacts can be mitigated by increased supplementary feed stores (Wilson et al. 2011b; Wilson et al. 2013). Second, horticultural farms are more vulnerable to tephra fallout and impact depends on additional factors such as crop season, crop maturity, amount of rainfall following the eruption, and dryness of plant leaves (Thompson et al. 2016). Following Jenkins et al. (2015b), disruption to crops starts with accumulations of $1-5 \mathrm{~kg} / \mathrm{m}^{2}$, gradually increasing to total crop loss at accumulations $>100 \mathrm{~kg} / \mathrm{m}^{2}$ due to 
Table 7 Summary of the exposure for municipalities across the study area (Figs. 1 and 8)

\begin{tabular}{|c|c|c|c|c|c|c|c|c|c|c|c|c|c|c|}
\hline \multirow[t]{3}{*}{ Municipalities } & \multicolumn{8}{|l|}{ Exposure } & \multicolumn{4}{|l|}{ Hazard } & \multicolumn{2}{|l|}{ Impact } \\
\hline & \multirow[t]{2}{*}{ Population } & \multicolumn{4}{|c|}{ Area $\left(\mathrm{km}^{2}\right)$} & \multirow[t]{2}{*}{ Roads (km) } & \multirow[t]{2}{*}{ Score } & \multirow[t]{2}{*}{ Rank } & \multicolumn{2}{|c|}{ Tephra mass $\left(\times 10^{7} \mathrm{~kg}\right)$} & \multirow[t]{2}{*}{ Score } & \multirow[t]{2}{*}{ Rank } & \multirow[t]{2}{*}{ Score } & \multirow[t]{2}{*}{ Rank } \\
\hline & & Total & $\%$ tot. & Built & Agri. & & & & $25 \%$ & $75 \%$ & & & & \\
\hline Aira & 75,964 & 231 & 100 & 17 & 47 & 1249 & 0.19 & 7 & 2.02 & - & $1.9 \times 10^{-4}$ & 12 & $3.7 \times 10^{-5}$ & 11 \\
\hline Higashikushira & 7023 & 28 & 100 & 4 & 21 & 264 & 0.04 & 17 & 7.73 & 0.07 & $7.4 \times 10^{-4}$ & 11 & $3.2 \times 10^{-5}$ & 12 \\
\hline Hioki & 50,809 & 254 & 100 & 8 & 77 & 1308 & 0.17 & 10 & 0.09 & - & $8.3 \times 10^{-6}$ & 15 & $1.4 \times 10^{-6}$ & 15 \\
\hline Ichikikushikino & 30,220 & 111 & 56 & 2 & 19 & 349 & 0.05 & 16 & 0.05 & - & $4.4 \times 10^{-6}$ & 16 & $2.3 \times 10^{-7}$ & 16 \\
\hline Kagoshima & 609,250 & 546 & 100 & 85 & 124 & 4120 & 0.96 & 1 & 3979.30 & 2145.25 & $3.8 \times 10^{-1}$ & 1 & $3.7 \times 10^{-1}$ & 1 \\
\hline Kanoya & 105,607 & 448 & 94 & 22 & 186 & 2725 & 0.38 & 3 & 1391.50 & 57.19 & $1.3 \times 10^{-1}$ & 3 & $5.1 \times 10^{-2}$ & 2 \\
\hline Kimotsuki & 16,805 & 308 & 42 & 3 & 34 & 553 & 0.07 & 15 & 7.90 & 0.05 & $7.5 \times 10^{-4}$ & 10 & $5.1 \times 10^{-5}$ & 10 \\
\hline Kirishima & 128,156 & 604 & 85 & 26 & 131 & 2803 & 0.38 & 4 & 236.30 & 5.82 & $2.3 \times 10^{-2}$ & 6 & $8.5 \times 10^{-3}$ & 5 \\
\hline Mimata & 25,851 & 110 & 56 & 7 & 20 & 363 & 0.07 & 14 & 11.16 & 0.09 & $1.1 \times 10^{-3}$ & 9 & $7.7 \times 10^{-5}$ & 9 \\
\hline Minamikyushu & 38,481 & 358 & 74 & 5 & 96 & 1529 & 0.17 & 9 & 0.09 & - & $9.0 \times 10^{-6}$ & 14 & $1.5 \times 10^{-6}$ & 14 \\
\hline Minamisatsuma & 37,446 & 282 & 47 & 5 & 46 & 855 & 0.11 & 11 & $<0.01$ & - & $1.0 \times 10^{-7}$ & 17 & $1.1 \times 10^{-8}$ & 17 \\
\hline Miyakonojo & 170,547 & 653 & 78 & 49 & 223 & 2950 & 0.56 & 2 & 53.71 & 0.48 & $5.1 \times 10^{-3}$ & 8 & $2.9 \times 10^{-3}$ & 7 \\
\hline Osaki & 14,358 & 102 & 100 & 3 & 63 & 717 & 0.09 & 12 & 153.07 & 3.05 & $1.5 \times 10^{-2}$ & 7 & $1.3 \times 10^{-3}$ & 8 \\
\hline Satsumasendai & 99,138 & 684 & 52 & 14 & 96 & 1893 & 0.26 & 5 & 0.22 & - & $2.1 \times 10^{-5}$ & 13 & $5.5 \times 10^{-6}$ & 13 \\
\hline Shibushi & 33,492 & 289 & 94 & 8 & 121 & 1511 & 0.19 & 8 & 238.24 & 5.46 & $2.3 \times 10^{-2}$ & 5 & $4.3 \times 10^{-3}$ & 6 \\
\hline Soo & 39,415 & 390 & 100 & 9 & 152 & 2011 & 0.24 & 6 & 520.74 & 14.20 & $5.0 \times 10^{-2}$ & 4 & $1.2 \times 10^{-2}$ & 4 \\
\hline Tarumizu & 16,702 & 162 & 100 & 6 & 26 & 569 & 0.07 & 13 & 3863.15 & 380.41 & $3.7 \times 10^{-1}$ & 2 & $2.7 \times 10^{-2}$ & 3 \\
\hline
\end{tabular}

The population and total area fields are relative to the entire municipality, whereas the fields built, agriculture (i.e., Agri.), roads, and tephra mass are relative to the fraction of the municipality included in the study area (i.e., field \% tot.). See text for details on the calculation of exposure, hazard, and impact scores and ranks

physical impacts, burial of crops, and changes in soil processes due to the formation of impermeable tephra crusts (Magill et al. 2013). Note that for both pastoral and horticultural farms, accumulations at $>100 \mathrm{~kg} / \mathrm{m}^{2}$ also result in the burial/damage of assets such as irrigation systems and greenhouses.

Figure $8 \mathrm{~b}$ and Table 6 summarize the area of agricultural land affected by tephra fallout. A threshold of $1 \mathrm{~kg} / \mathrm{m}^{2}$ (i.e., the onset of minor damage potentially leads to losses $<50 \%$ and for which mitigation measures are possible; Wilson et al. 2013; Jenkins et al. 2015a; Craig et al. 2016a). This affects between $57 \mathrm{~km}^{2}$ (75\% probability) and $632 \mathrm{~km}^{2}$ (25\% probability) of agricultural lands. An accumulation of $100 \mathrm{~kg} / \mathrm{m}^{2}$ represents the onset of total losses and potentially affects 3.5$19.3 \mathrm{~km}^{2}$.

\section{Electricity network}

Wardman et al. (2012) identify a critical value of $3 \mathrm{~mm}$ of tephra (i.e., $\sim 3-6 \mathrm{~kg} / \mathrm{m}^{2}$ here) as a critical threshold for electrical insulators potentially leading to flashovers, especially when the tephra is wet. Our analysis shows that tephra accumulations of 1 and $10 \mathrm{~kg} / \mathrm{m}^{2}$ have a $25 \%$ probability to affect 51 and $22 \mathrm{~km}$ of power lines, respectively. An accumulation of $1 \mathrm{~kg} / \mathrm{m}^{2}$ has probabilities of 75 and $25 \%$ to affect 0.2 and $2.1 \mathrm{~km}^{2}$ of solar panels, respectively.

\section{Population}

Table 6 summarizes the exposure and the estimated tephra accumulation per municipality considering probabilities of occurrence of the hazard of 25 and 75\% (Fig. 6). The most populated municipality is by far Kagoshima (609,250 inhabitants, $85 \mathrm{~km}^{2}$ of built area) followed by Miyakonojo (170,547 inhabitants, $49 \mathrm{~km}^{2}$ of built area), Kirishima (128,156 inhabitants, $26 \mathrm{~km}^{2}$ of built area), and Kanoya (105,607 inhabitants, $22 \mathrm{~km}^{2}$ of built area), with the remaining municipalities containing $<100,000$ inhabitants and $<20 \mathrm{~km}^{2}$ of the total built area. In general, it can be estimated that between 1.1 and 1.5 million people are exposed to tephra fallout (regardless of the accumulation; Table 7).

\section{Ranking per municipality}

The municipalities of Kagoshima, Miyakonojo, Kanoya, and Kirishima have the highest exposure scores in the study area (Table 7). The high scores of Kagoshima and Miyakonojo are the result of extended urban centers correlating with large populations and a major road network. While the four 
municipalities with the highest hazard scores are Kagoshima, Tarumizu, Kanoya, and Kirishima, the municipalities of Kagoshima, Kanoya, Tarumizu, and Soo result in the highest impact scores following a future Plinian eruption of Sakurajima (Table 7).

The only purpose of such a simple classification is a rapid comparison of municipality-wide impacts within the study area and is limited by the definition of indicators of impact. For instance, this approach ignores the importance of critical infrastructures within municipalities, such as the Tarumizu City Hall, in charge of the coordination daily cleanup strategies for the current vulcanian behavior at Sakurajima, or the importance of the Kagoshima Airport and Kokubu Central Station in the municipality of Kirishima (Magill et al. 2013; Jenkins et al. 2015b). Additionally, the ranking is based purely on exposure, and does not express the intensity of the impact, which requires a vulnerability assessment of exposed infrastructures (e.g., Spence et al. 2005; Marti et al. 2008; Wilson et al. 2012b; Jenkins et al. 2014b; Jenkins et al. 2015b; Hayes et al. 2015; Craig et al. 2016a).

\section{Estimated cost of cleanup operations}

Table 8 summarizes the cost of cleanup operations per municipality. For the road network, a total length of $612-3735 \mathrm{~km}$ is exposed to accumulations $\geq 1 \mathrm{~kg} / \mathrm{m}^{2}$, which represent a cleaning cost of 30-229 million JPY (US\$0.3-2 million). A mass of tephra of 14-132 $\times 10^{5} \mathrm{~kg}$ is estimated over urban areas, translating to a total cost to municipalities ranging between 3116 and 30,396 million JPY (US\$27-269 million) if the entire amount of tephra is removed. This assumption is likely to result in an over-estimation of the cleaning cost since Magill et al. (2013) estimate that $28.5 \%$ of the tephra produced by the 2011 Shinmoedake eruption was removed by government-supervised cleanup operations, leaving $71.5 \%$ cleaned through either private actions or natural remobilization. Although this consideration would scale down the tephra mass to cleanup to $4-38 \times 10^{5} \mathrm{~kg}$ and the cost to municipalities to 9-65 million JPY, we consider these numbers as a minimum because the proportion of removed tephra over the total tephra per unit area has been shown to increase for larger accumulations (Hayes et al. 2015).

Several caveats should be considered in our estimates of the cleanup costs. First, multiple stakeholders are involved in cleanup operations and include municipal authorities, insurance companies, and business owners (Hayes et al. 2015). The efficiency of cleanup operations also influences the overall economic impact of eruptions in urban areas (McDonald et al. 2017). Our simple approach does not allow forecasting such complex patterns and should not be seen as more than a linear extrapolation of the cost observed during the 2011 Shinmoedake eruption used to provide a first-order estimate of the cost to municipalities only. Second, the cleanup costs for the urban area in Miyazaki reported by Magill et al. (2013) also comprise the cleanup costs of the road network. As a result, the total cleanup costs shown in Table 8 should be smaller than the addition of the costs of cleanup operations on the road network and urban areas. Finally, more complex cleanup models in urban environments (e.g., Hayes et al. 2017) are likely to result in a more precise estimate of the total costs but require specific model inputs that go beyond the capabilities of our global georeferenced dataset.

Despite these caveats, costs reported in Table 8 are still helpful to produce a qualitative ranking of the cleanup costs for the various municipalities in our study area. Tarumizu is the most exposed municipality to high costs followed by Kagoshima and the municipalities located downwind (Kanoya, Miyakonojo, and Soo).

\section{Discussion}

\section{Hazard assessment}

A future large-scale explosive eruption of Sakurajima volcano is likely to result in the deposition of tephra fall with volumes that are orders of magnitude larger than those produced by the ongoing vulcanian activity (Tajima et al. 2013) and will be subject to a different influence of the wind. The strong change in wind direction from an eastward to a westward dispersal during the summer is more important for altitudes below $2 \mathrm{~km}$ asl, and, although likely to strongly affect the deposition patterns of vulcanian explosions (Durand et al. 2001), higher plumes will be influenced by the interaction with wind conditions at higher altitudes (Fig. 3).

Historical reports outline the multi-stage nature of historical large-scale eruptions of Sakurajima, which adds various levels of uncertainty in the assessment of future eruptions. First, eruption sequences described by Omori (1914) and Kotô (1916) suggest that the eruptions of Bunmei, Anei, and Taisho exhibited a large variability of eruption styles ranging from lava flow effusion to sustained paroxysmal phases dominated by convective plumes (with additional ash emission and vulcanian activity) over the course of a few weeks. As a result, each style is associated with distinct hazards: volcanic tremor, shockwaves, ballistics, volcanogenic or seismically induced tsunamis, pyroclastic density currents, lahars, and lava flows. Regarding tephra accumulation, a large part of the Sakurajima peninsula is likely to be in the zone defined as destructive and potentially life-threatening by Jenkins et al. (2015b). Because the only road connection to the mainland is located on the main wind dispersal axis (Figs. 5 and 6), evacuations by boat should be included in emergency plans. Secondly, none of the considered eruptions originated from the same source, with new vents forming along fissure systems and, in the case of the Anei eruption, up to four vents being simultaneously active during the initial stage of the eruption including 
Table 8 Estimates of cleanup costs (in million JPY) on the built environment and roads to the municipality based on data from Magill et al. (2013)

\begin{tabular}{|c|c|c|c|c|c|c|c|c|}
\hline \multirow[t]{2}{*}{ Municipality } & \multicolumn{2}{|c|}{$\begin{array}{l}\text { Tephra mass in } \\
\text { urban areas } \\
\left(\times 10^{7} \mathrm{~kg}\right)\end{array}$} & \multicolumn{2}{|c|}{$\begin{array}{l}\text { Estimated cleanup } \\
\text { cost in urban areas } \\
\left(\times 10^{6} \mathrm{JPY}\right)\end{array}$} & \multicolumn{2}{|c|}{$\begin{array}{l}\text { Road length }(\mathrm{km}) \\
\text { with accumulation } \\
>1 \mathrm{~kg} / \mathrm{m}^{2}\end{array}$} & \multicolumn{2}{|c|}{$\begin{array}{l}\text { Estimated roads } \\
\text { cleanup cost } \\
\left(\times 10^{6} \mathrm{JPY}\right)\end{array}$} \\
\hline & $25 \%$ & $75 \%$ & $25 \%$ & $75 \%$ & $25 \%$ & $75 \%$ & $25 \%$ & $75 \%$ \\
\hline Aira & 0.47 & - & 108 & - & - & - & - & - \\
\hline Higashikushira & 0.77 & 0.01 & 177 & 2 & 62 & - & 44 & - \\
\hline Hioki & $<0.01$ & - & 1 & - & - & - & - & - \\
\hline Ichikikushikino & $<0.01$ & - & $<1$ & - & - & - & - & - \\
\hline Kagoshima & 23.11 & 7.91 & 5316 & 1820 & 128 & 88 & 6 & 4 \\
\hline Kanoya & 12.11 & 0.39 & 2785 & 90 & 725 & 238 & 36 & 12 \\
\hline Kimotsuki & 0.29 & $<0.01$ & 66 & $<1$ & 11 & - & 1 & - \\
\hline Kirishima & 6.86 & 0.09 & 1578 & 21 & 309 & 71 & 16 & 4 \\
\hline Mimata & 1.44 & 0.01 & 330 & 2 & 122 & - & 6 & - \\
\hline Minamikyushu & $<0.01$ & - & $<1$ & - & - & - & - & - \\
\hline Minamisatsuma & - & - & - & - & - & - & - & - \\
\hline Miyakonojo & 9.37 & 0.06 & 2156 & 14 & 378 & - & 19 & - \\
\hline Osaki & 2.30 & 0.03 & 529 & 8 & 278 & 7 & 14 & - \\
\hline Satsumasendai & $<0.01$ & - & 1 & - & - & - & - & - \\
\hline Shibushi & 5.43 & 0.11 & 1249 & 25 & 630 & - & 32 & - \\
\hline Soo & 9.06 & 0.21 & 2084 & 48 & 877 & 90 & 44 & 5 \\
\hline Tarumizu & 60.94 & 4.72 & 14,016 & 1086 & 214 & 118 & 11 & 6 \\
\hline Total & 132.15 & 13.55 & 30,396 & 3116 & 3735 & 612 & 229 & 30 \\
\hline $28.50 \%$ & - & - & 8663 & 888 & - & - & - & - \\
\hline $80 \%$ & - & - & 24,317 & 2493 & - & - & - & - \\
\hline
\end{tabular}

The total cleanup cost in urban areas is also scaled considering the removal of $28.5 \%$ (Magill et al. 2013) and $80 \%$ (Hayes et al. 2015) of the total tephra accumulation. Note that (i) the cleanup cost in urban areas is based on the assumption that the total tephra accumulation is removed and therefore represents a maximum (Hayes et al. 2015) and (ii) the cleanup cost in urban areas comprises the cleanup cost of the road network; the total cleanup cost is therefore less than the sum of the two costs shown here two that generated tephra plumes reaching altitudes of $12 \mathrm{~km}$ asl (Kotô 1916). As a result, an uncertainty exists on the number, location, and geometry of the vents during the next eruption. Activity from submarine vents dominated the final part of the Anei eruption and cannot be excluded during a future reactivation. Although the impact of such an uncertainty on the medial and distal hazard is unclear, implications for the emergency management on the Sakurajima peninsula are important.

\section{Impact}

Assessing the impact of tephra fallout is more complex than applying a simple relationship to the deposit thickness. Socioeconomic losses and disruptions depend on the interaction of factors such as volcanological aspects (i.e., style, duration and timing of eruption, grain size, accumulation rates, content of soluble acidic salts, weather conditions during the eruption), the nature of the exposed infrastructure and assets, the presence of pre-existing vulnerabilities, and the resilience of communities to economic, environmental, political, and social variables (Johnston et al. 2000; Chester et al. 2002; Gregg et al.
2004; Ort et al. 2008; Bird et al. 2009; Marrero et al. 2010; Wilson et al. 2012b; Bird and Gísladóttir 2012; Magill et al. 2013; Craig et al. 2016a).

This section discusses the outcomes of the exposure analysis in the perspective of the post-event impact assessment of Magill et al. (2013) after the 2011 eruption of Shinmoedake, which provides a similar socio-economical reference to identify impacts of a future eruption of Sakurajima. The comparison of the VEI 4 scenario developed here with the 2011 VEI 2 eruption of Shinmoedake (unit 2, 27 January; Miyabuchi et al. 2013; Maeno et al. 2014) suggests a wider area of direct physical impacts related to tephra fallout in the case of a future Plinian eruption of Sakurajima (i.e., zones I and II of Jenkins et al. 2015b) and a larger component of ash related to a more intense magmatic fragmentation. No forecast of the chemical composition and potential related impacts is possible.

\section{Existing mitigation measures}

Following Wilson et al. (2014), risk mitigation strategies include (i) land use planning used to decrease exposure of 
people, buildings, and infrastructure to natural hazards; (ii) system and component design to improve resilience if exposed to natural hazards; and (iii) contingency planning (i.e., preparedness and response) which is used to reduce the impacts of the different hazards and decrease restoration and recovery times. In this aspect, efficient measures are already implemented in the Kagoshima prefecture to mitigate the impacts of daily vulcanian explosions at Sakurajima, including a cleaning plan, ash-resistant buildings, volcanic bomb shelters, sabo damns (e.g., structures to dissipate lahar energy), adapted critical services (e.g., as protected wastewater treatment plans and electrical insulators), and annual evacuation drills (Deguchi 1991; Durand et al. 2001; Magill et al. 2013; Jenkins et al. 2015b; Hayes et al. 2015). As a result, during the 2011 eruption of Shinmoedake, the efficiency of the sealed sewage and water supply network avoided any contamination by ash and remained functional in Kagoshima throughout cleanup operations (Magill et al. 2013). Where no management plan was established prior to the eruption, organizations proved to be highly adaptive, with adequate resources and staff available and in constant communication with regional and national networks, all contributing to an efficient management of the crisis (Magill et al. 2013).

\section{Transportation network}

Road network An estimated $480 \mathrm{~km}$ of roads was covered by an accumulation $\geq 1 \mathrm{~kg} / \mathrm{m}^{2}$ following the 2011 eruption of Shinmoedake volcano (using the motorway, trunk, primary, secondary, tertiary, and urban classes of Magill et al. 2013), including $3.2 \mathrm{~km}$ of the Miyazaki expressway. In Takaharu town, located $12 \mathrm{~km}$ away from the vent, the local government was reportedly responsible for cleaning $307 \mathrm{~km}$ of roads, prioritizing roads used for a potential evacuation (Magill et al. 2013). An estimated 44 sweeper trucks were used, cleaning major roads within a week and rural roads within 2 months (Magill et al. 2013). Road cleanup operations were responsible for $44 \%$ of the total cost of road cleanup operations in Takaharu.

Over the most exposed municipalities, our study suggests that a total road length ranging between 612 (75\% probability) and $3735 \mathrm{~km}$ (25\% probability) is exposed to accumulations $\geq 1 \mathrm{~kg} / \mathrm{m}^{2}$ (Table 8 ). Table 8 reveals how the geographical location of municipalities to the eruptive vent affects the exposure as a function of the exceedance probability of the hazard. Although a probability of $75 \%$ always results in a smaller part of the road network being impacted than the $25 \%$ probability, this influence is less pronounced for municipalities close to the vent (e.g., Kagoshima, Tarumizu, Kirishima Kanoya) than those further away (e.g., Miyakonojo, Shibushi). For instance, the impact in Kagoshima varies between 88 and $128 \mathrm{~km}$ (probabilities of 75 and 25\%, respectively). In contrast, in the municipality of Shibushi, $630 \mathrm{~km}$ of roads have a $25 \%$ probability to be affected by tephra fallouts $\geq 1 \mathrm{~kg} / \mathrm{m}^{2}$, but the road network is virtually unaffected when an exceedance probability of $75 \%$ is considered.

Railroad network During the 2011 eruption of Shinmoedake, approximately $186 \mathrm{~km}$ of rail tracks were exposed to tephra fallout, causing cancelations for about a week after the eruption due to the mechanical failure of track switches and loss of electrical contact between the track and train wheels (Magill et al. 2013). Tephra also increased the abrasion of mechanical parts, costing an additional 66 million JPY to JR Kyushu Railway Company.

Mitigation measures exist to reduce the impact of tephra from frequent vulcanian eruptions of Sakurajima on the railroad network, including the use of lower viscosity oil to avoid clogging by ash, an established cleaning protocol, and the presence of an automated cleaning system on the Kagoshima Shinkansen line. Lessons learned from the 2011 eruption of Shinmoedake revealed that the principal limitation of these measures was their design for facing tephra volumes from vulcanian explosions, with a subplinian VEI 2 eruption resulting in an unexpected magnitude of disruptions of the network (Magill et al. 2013).

Our analysis indicated that Sakurajima constitutes a lower threat to the railroad network than Shinmoedake, with $56 \mathrm{~km}$ of tracks having a $25 \%$ probability of suffering $1 \mathrm{~kg} / \mathrm{m}^{2}$ of tephra accumulation (Table 6), mostly concentrated on the Nippo main lines and Kitto lines. The summer season decreases the hazard to all stations considered here except for the Kokubu station (Table 5).

Airports and air traffic In addition to the Kagoshima airport (Figs. 1 and 7), two military bases (Nyutabaru and Kanoya) are present in the study area and one commercial airport is located east of the study area in the Miyazaki prefecture. All airports are exposed to tephra fallout and potential cleanup operations, with the airports of Kanoya and Kagoshima both being exposed to highest exceedance probabilities and largest tephra accumulations. Eighteen commercial flights connect to the Kagoshima Airport, including 12 domestic and six international flights to China, Korea, and Taiwan. The Miyazaki Airport has nine internal and two international flights to Korea and Taiwan (OpenFlights.org 2016).

During the 2011 Shinmoedake eruption, the Tokyo VAAC released 140 Volcanic Ash Advisories between January and March, and the Miyazaki Airport was closed several times resulting in 22\% fewer passengers (Magill et al. 2013). Although our assessment does not account for the hazard related to the atmospheric dispersal of ash, it is likely that both Kagoshima and Miyazaki airports will suffer interruptions to allow cleanup operations. Additionally, Kotô (1916) reports episodes of ash fallout on Tokyo one day after the onset of the explosive phase of the 1914 Taisho eruption. This suggests 
that (i) all 10 commercial airports in Kyushu and (ii) airports in South Honshu, including the main Tokyo airports (e.g., Haneda and Narita), can potentially suffer closures. Ash was also observed as far as the Bonin Islands, $\sim 1200 \mathrm{~km}$ eastsoutheast of Sakurajima (Kotô 1916).

\section{Electricity network}

The generation and distribution of electricity in Kyushu rely on 11 hydroelectric, three nuclear, 12 thermal, and five geothermal power plants (Durand et al. 2001) connected through $110-, 220-$, and $500-\mathrm{kV}$ transmission lines, which stepped down to 66 and $6 \mathrm{kV}$ for distribution and to 220 and $110 \mathrm{~V}$ in urban and rural areas (Magill et al. 2013). The most frequent impacts of tephra on high voltage power networks include current leakage and flashovers, which are highly dependent on the physical and chemical properties that influence conductivity and resistivity of the ash (Wardman et al. 2012). Additional factors such as the insulator condition and the weather conditions will determine the degree of ash adherence to insulators (Wardman et al. 2012).

During the 2011 Shinmoedake eruption, despite $259 \mathrm{~km}$ of power lines being exposed to tephra fall (including $24 \mathrm{~km}$ exposed to $3 \mathrm{~kg} / \mathrm{m}^{2}$ and $10 \mathrm{~km}$ to $10 \mathrm{~kg} / \mathrm{m}^{2}$ ) and a high content of soluble salts which made the ash highly conductive when wet, no disruption of the transmission network occurred. However, reports of flashover and leakage occurred on the distribution network for 4 months after the eruption, causing temporary interruptions of supply. Note that most incidents occurred on insulators showing traces of physical abrasion by tephra during a period of light misty rain 7-10 days after the eruption (Magill et al. 2013).

Our dataset of electric lines allows for quantitative comparison with a possible large eruption of Sakurajima, suggesting that similar impacts can be expected. It is unclear what effect seasonality could have on the impact level, as summer months are characterized by both the weakest surface winds and the most intense episode of rainfall compared to the rest of the year.

Preventive measures on the electricity network include an efficient isolation of overhead cables to mitigate impacts of ash from Sakurajima (note that there has been no report of interruption attributed to the current vulcanian style of eruption), as well as sea salt and industrial pollution on insulators (Durand et al. 2001; Magill et al. 2013). Additionally, lessons learned during the Shinmoedake eruption led to the development of a new strategy for the cleaning of electrical facilities likely to be useful for any future eruption. It is interesting to note that the cleaning process was slowed down by the disruption of the road network (Magill et al. 2013).

The classification of the Landsat scene also allowed the identification of up to $2 \mathrm{~km}^{2}$ of solar panels exposed to accumulations of $1 \mathrm{~kg} / \mathrm{m}^{2}$. High-resolution satellite images suggest an important use of photovoltaic systems in rural areas. Magill et al. (2013) report breakage of solar panels by lapilli-sized clasts up to a distance of $14 \mathrm{~km}$ from Shinmoedake. Zorn and Walter (2016) estimate a mean reduction of the total power generated by photovoltaic units by $80 \%$ following an accumulation of $0.1 \mathrm{~kg} / \mathrm{m}^{2}$ of fine ash.

\section{Agriculture}

Table 9 summarizes the agricultural resources in South Kyushu as obtained from the 2010 census of Agriculture and Forestry (Ministry of Agriculture Forestry and Fishery 2010). Note that the reason for the large discrepancy between areas reported in Tables 6 and 9 is unclear but is most likely partly related to the census methodology (e.g., reports of farms belonging to a cooperative only). There are 123,906 farm households (76,813 commercial and 47,093 noncommercial) with a total population of 131,440 people engaged in farm work. Dominant crops are industrial crops and vegetables, though the proportion of outdoor versus indoor activity is unclear (Table 9).

During the 2011 Shinmoedake eruption, $564 \mathrm{~km}^{2}$ of agricultural land was affected by tephra fallout (including $30 \mathrm{~km}^{2}$ exposed to accumulations $>10 \mathrm{~kg} / \mathrm{m}^{2}$ ) resulting in an estimated cost of 1204 million JPY partitioned between reduced or lost crops and land rehabilitation (Magill et al. 2013). Overall, physical impacts dominated over chemical impacts, and the rapid implementation of a response plan mitigated any medium- to long-term effects of tephra fall. Regarding outdoor crops, the timing of the eruption (with most crops harvested in November-December leaving only tea, potatoes, and spinach at risk), adequate mitigation measures (e.g., removal of tephra from plants and ploughing remaining ash into soil), and cleanup and rehabilitation support from the central government resulted in a low level of losses. Greenhouses offered good protection against the direct impact of tephra fall but resulted in indirect effects including the reduction of photosynthesis and the blockage of openings for aeration and ventilation, increasing humidity and the risk of disease (Magill et al. 2013). At the time of the eruption, forage crops were germinating and becoming established and thus vulnerable to ash contamination, resulting in the central government issuing a recommendation that fresh grass was not to be used for feeding animals. The impact on livestock was limited as they were kept indoors, but 207 lightly constructed sheds and warehouses were partially damaged by the load of tephra (Magill et al. 2013).

Forecasting the impact on agriculture is difficult due to reasons previously stated (e.g., Wilson et al. 2011a; Magill et al. 2013; Craig et al. 2016a; Stewart et al. 2016; Thompson et al. 2016; Craig et al. 2016b). However, our exposure analysis estimates that $57-632$ and $9-202 \mathrm{~km}^{2}$ are exposed to accumulations of 1 and $10 \mathrm{~kg} / \mathrm{m}^{2}$, 
Table 9 Agricultural resources in South Kyushu (from Ministry of Agriculture Forestry and Fishery 2010)

Land area of commercial farming

\begin{tabular}{|c|c|c|c|c|c|c|c|c|c|c|c|}
\hline & Total & Paddy rice & $\begin{array}{l}\text { Wheat and } \\
\text { barley }\end{array}$ & $\begin{array}{l}\text { Miscellaneous } \\
\text { cereals }\end{array}$ & Potatoes & Pulses & $\begin{array}{l}\text { Industrial } \\
\text { crops }\end{array}$ & Vegetables & $\begin{array}{l}\text { Flowers and } \\
\text { ornamental } \\
\text { trees }\end{array}$ & $\begin{array}{l}\text { Other } \\
\text { crops }\end{array}$ & $\begin{array}{l}\text { Fruit } \\
\text { trees }\end{array}$ \\
\hline $\begin{array}{l}\text { Area } \\
\qquad\left(\mathrm{km}^{2}\right)\end{array}$ & 76.0 & 6.6 & 0.6 & 1.3 & 14.7 & 2.6 & 21.1 & 19.2 & 2.8 & 5.8 & 1.3 \\
\hline$\%$ & 100.0 & 8.7 & 0.8 & 1.7 & 19.4 & 3.4 & 27.8 & 25.3 & 3.6 & 7.6 & 1.7 \\
\hline \multicolumn{12}{|c|}{ Grazing land area } \\
\hline & Total & $\begin{array}{l}\text { National } \\
\quad \text { ownership }\end{array}$ & $\begin{array}{l}\text { Private } \\
\quad \text { ownership }\end{array}$ & & & & & & & & \\
\hline $\begin{array}{l}\text { Area } \\
\qquad\left(\mathrm{km}^{2}\right)\end{array}$ & 52.0 & 13.7 & 38.3 & & & & & & & & \\
\hline$\%$ & 100.0 & 26.3 & 73.7 & & & & & & & & \\
\hline \multicolumn{12}{|c|}{ Commercial livestock } \\
\hline & Total & Dairy cows & Beef cattle & Pigs & Layers & Broilers & & & & & \\
\hline Heads & $2,136,224$ & 3355 & 138,264 & $1,284,930$ & 90,170 & 619,505 & & & & & \\
\hline$\%$ & 100.0 & 0.2 & 6.5 & 60.1 & 4.2 & 29.0 & & & & & \\
\hline
\end{tabular}

respectively (Table 6). The Taisho eruption occurred in January and resulted in a loss between 60 and $80 \%$ of wheat, vegetable, fruit, sugarcane, and tobacco crops (Durand et al. 2001), but did not benefit from the level of preparedness that the central organizations possess today or their ability to initiate rapid and efficient response plans. In our study area, the municipality of Kanoya presents the highest exposure of agricultural lands to tephra accumulations.

\section{Fishery}

Although little damage to the fishing industry was reported following the 2011 eruption of Shinmoedake, Sakurajima is surrounded by the Kagoshima Bay which hosts an important fishing industry (Durand et al. 2001) with an estimated 7200 people employed in fishery-related activities in Southern Kyushu (Ministry of Agriculture Forestry and Fishery 2010). Historical large eruptions are reported to have been associated with pumice rafts affecting Kagoshima Bay (Omori 1914). As a consequence of pumice rafts produced by the 2011 eruption of Cordón Caulle on lakes, the water surface was covered by lapilli-sized pumice clasts and the water concentration of fine ash was increased, thus reducing the levels of ultraviolet light necessary for the development of microorganisms and resulting in impacts higher in the food chain (Elissondo et al. 2016). The direct impact on fish populations varied as a function of species and included displacements, ingestion of fine ash, and burial of niches. Additional impacts include the physical abrasion of boats and engines (Elissondo et al. 2016).

\section{Cleaning}

An estimated $106 \mathrm{~km}^{2}$ of urban land was affected by tephra fallout during the 2011 eruption of Shinmoedake (with a tephra mass of $1470 \times 10^{6} \mathrm{~kg}$ ), and although no prior plan was in place for the cleanup operations, the good organization of local governments resulted in a rapid assignment of individual responsibilities and a quick and efficient emergency response (Magill et al. 2013). The experience gained during the Shinmoedake eruption is likely to have increased the level of preparedness for future volcanic crises. Although the demand for water required for cleanup operations after eruptions typically increases by $20 \%$ (Wilson et al. 2012b; Hayes et al. 2015), mitigation measures implemented on the water management system in South Kyushu allowed a continuous supply of water for the spraying of ash to avoid remobilization while collecting tephra.

Taking the example of Takaharu town, the remobilization and infiltration of the fine ash fraction caused cleanup operations to extend for longer than 8 months despite a short-lasting eruption of a relatively small volume. Teams of five people were assembled to help with the cleaning of houses, with a rate of four houses per day being cleaned per team. It took 1 week to clean the major roads and up to 2 months to complete the cleaning of rural roads (Magill et al. 2013). The total cost of cleaning operations was 35 million JPY over the period 2010 2011 , of which $6.8 \%$ were due to the manufacture of tephra collection bags, $13.8 \%$ were due to the collection and transfer of tephra, $35.5 \%$ were due to the removal of tephra from agricultural facilities, and $43.9 \%$ were due to road cleanup operations. 
Our analysis suggests that the built environment can potentially be affected by $14-132 \times 10^{7} \mathrm{~kg}$ of tephra. Although it is surprising that the total tephra mass from a VEI 4 eruption scales with the tephra mass from the VEI 2 Shinmoedake eruption (i.e., $1470 \times 10^{6} \mathrm{~kg}$, Magill et al. 2013), this can be explained by the fact that (i) our study area does not include the easternmost accumulations (Figs. 5 and 6), (ii) Sakurajima is mostly surrounded by the Kagoshima Bay and only $6 \mathrm{~km}^{2}$ of built environment of Tarumizu is affected by heavy tephra accumulations, and (iii) total tephra masses presented by Magill et al. (2013) are calculated as an extrapolation of observations on the city of Miyakonojo to the entire area.

\section{Sources of uncertainty}

Pre-event impact and risk assessments are associated with uncertainties in every component of the multi-disciplinary approach they require, which all combine and propagate to final impact estimates. Uncertainties are associated with the characterization of the tephra deposits (Biass and Bonadonna 2011; Engwell et al. 2013; Biass et al. 2014a; Klawonn et al. 2014; Engwell et al. 2015; Bonadonna et al. 2015), the modeling procedure (Scollo et al. 2008), the characterization of the hazard (Selva et al. 2010), the use of geo-spatial datasets (Renschler 2005), or institutional responses during volcanic crises (Metzger et al. 1999; Hincks et al. 2014). Here, we estimate that the principal source of uncertainty for our exposure analysis lies in the accuracy and completeness of global geo-spatial datasets.

Specifically, OpenStreetMap is a collaborative mapping effort providing all geo-referenced features in open-source, which has shown its value in various humanitarian crises (e.g., Zook et al. 2010; Meier 2012) and has been used in volcanic contexts (e.g., Biass et al. 2013; Magill et al. 2013; Scaini et al. 2014). Personal experience allowed us to identify several limitations including (i) the accuracy, (ii) the completeness, and (iii) the consistency of the dataset. First, despite a rigorous mapping methodology required from the contributors, most of the mapping is performed either by handheld GPS or by the digitization of geo-referenced maps and both methods are likely to be associated with spatial uncertainties on a metric order. Second, the completeness of the dataset has a first-order impact on exposure analyses that can only be overcome by ground validation. Third, within a given region of interest, there is usually a discrepancy in the completeness of the dataset between rural and urban areas, which is likely to introduce a bias in exposure analyses. Although all these sources of uncertainties should be considered, OpenStreetMap remains the most complete source of global geo-referenced data accessible in open-source.

\section{Conclusions}

We combined field characterization and historical reports of the last three large-scale (subplinian to Plinian) eruptions of Sakurajima volcano to develop a realistic eruption scenario. This was used as an input to a scenario-based probabilistic hazard assessment for tephra fallout. Because modeling limitations prevent the simulation of typical complex eruptive sequences observed at Sakurajima, our eruption scenario describes a 1-48-h-long climatic phase that reflects the peak in mass eruption rate. Main outcomes of the hazard assessment include the following:

- The presence of a general eastward dispersal, making the municipalities located downwind and in proximal areas the most exposed to tephra accumulations

- The warning that Sakurajima peninsula and parts of the municipality of Tarumizu will be exposed to tephra accumulations potentially leading to structural damages to buildings

- The finding that an increasing eruption duration (i.e., decreasing intensity) will increase the hazard in proximal areas and decrease it in distal areas

Combining a scenario-based probabilistic hazard assessment with a rapid exposure analysis reveals that an accumulation of $1 \mathrm{~kg} / \mathrm{m}^{2}$ during a future Plinian eruption of Sakurajima volcano could affect the following:

- $\quad 634-4668 \mathrm{~km}$ of roads (exceedance probabilities of 75 and $25 \%$, respectively) and $56 \mathrm{~km}$ of the railroad network ( $25 \%$ probability)

- $4-100 \mathrm{~km}^{2}$ of urban environment and $57-632 \mathrm{~km}^{2}$ of agricultural lands (exceedance probabilities of 75 and $25 \%$, respectively)

- a minimum of $22-51 \mathrm{~km}$ of electricity lines and between 0.2 and $2.1 \mathrm{~km}^{2}$ of solar panels (exceedance probabilities of 75 and $25 \%$, respectively)

Additionally, a simple exposure score suggests that the municipalities of Kagoshima, Kanoya, Tarumizu, and Soo are, in increasing order, the most exposed population centers to potential impacts.

In terms of methodology, open-source and communitybased datasets such as OpenStreetMap are an invaluable source of georeferenced data, but their use should always be associated with a quality check to assess their completeness. Regarding the land use map produced from a cloudfree Landsat 8 image, a multi-spectral classification is able to identify the extent of solar panels. This aspect is likely to be valuable when estimating the impact of tephra fall on electricity generation, especially with the increasing use of renewable energies. 
Acknowledgements All authors are grateful to B.F. Houghton for allowing the completion of this project, to C. Magill for her assistance with various datasets, and to Executive Editor Andy Harris, Editor Laura Sandri, and three anonymous reviewers who greatly contributed to improving this manuscript. Landsat data were accessed through the USGS Global Visualization Viewer.

Funding information S. Biass was supported by the Friedlander foundation and benefited from the additional support of the NSF EAR1427357 grant. C. Bonadonna was supported by the Swiss National Science Foundation grant no. 200021_156255. R. Cioni and M. Pistolesi benefited from the support of funds from M. Ripepe, who is greatly thanked. A. Todde was partially funded by PIA funds from the Earth Science Dept. of the University of Florence.

\section{References}

Aramaki S (1984) Formation of the Aira Caldera, southern Kyushu, 22, 000 years ago. J Geophys Res Solid Earth 89:8485-8501. https:// doi.org/10.1029/JB089iB10p08485

Ayris P, Delmelle P (2012) The immediate environmental effects of tephra emission. Bull Volcanol 74:1905-1936. https://doi.org/10.1007/ s00445-012-0654-5

Bagheri GH, Bonadonna C, Manzella I, Vonlanthen P (2015) On the characterization of size and shape of irregular particles. Powder Technol 270: 141-153. https://doi.org/10.1016/j.powtec.2014.10.015

Bagheri G, Rossi E, Biass S, Bonadonna C (2016) Timing and nature of volcanic particle clusters based on field and numerical investigations. J Volcanol Geotherm Res 327:520-530. https://doi.org/10. 1016/j.jvolgeores.2016.09.009

Biass S, Bagheri G, Aeberhard W, Bonadonna C (2014a) TError: towards a better quantification of the uncertainty propagated during the characterization of tephra deposits. Stat Volcanol 1:1-27. https://doi.org/ 10.5038/2163-338X.1.2

Biass S, Bonadonna C (2011) A quantitative uncertainty assessment of eruptive parameters derived from tephra deposits: the example of two large eruptions of Cotopaxi volcano, Ecuador. Bull Volcanol 73:73-90

Biass S, Bonadonna C (2014) TOTGS: total grainsize distribution of tephra fallout. In: https://vhub.org/resources/3297. https://vhub.org/ resources/3297. Accessed 30 Jan 2015

Biass S, Bonadonna C (2013) A fast GIS-based risk assessment for tephra fallout: the example of Cotopaxi volcano, Ecuador - part I: probabilistic hazard assessment. Nat Hazards 65:477-495

Biass S, Bonadonna C, Connor L, Connor C (2016a) TephraProb: a Matlab package for probabilistic hazard assessments of tephra fallout. J Appl Volcanol 5:1-16. https://doi.org/10.1186/s13617-0160050-5

Biass S, Bonadonna C, Traglia F et al (2016b) Probabilistic evaluation of the physical impact of future tephra fallout events for the Island of Vulcano, Italy. Bull Volcanol 78:1-22. https://doi.org/10.1007/ s00445-016-1028-1

Biass S, Frischknecht C, Bonadonna C (2013) A fast GIS-based risk assessment for tephra fallout: the example of Cotopaxi volcano, Ecuador-part II: vulnerability and risk assessment. Nat Hazards 65:497-521

Biass S, Scaini C, Bonadonna C et al (2014b) A multi-scale risk assessment for tephra fallout and airborne concentration from multiple Icelandic volcanoes - part 1: hazard assessment. Nat Hazards Earth Syst Sci 14:2265-2287. https://doi.org/10.5194/nhess-142265-2014

Bird D, Gisladottir G, Dominey-Howes D (2009) Resident perception of volcanic hazards and evacuation procedures. Nat Hazards Earth Syst Sci 9:251-266
Bird DK, Gísladóttir G (2012) Residents' attitudes and behaviour before and after the 2010 Eyjafjallajökull eruptions - a case study from southern Iceland. Bull Volcanol 74:1263-1279. https://doi.org/10. 1007/s00445-012-0595-Z

Black BA, Manga M, Andrews B (2016) Ash production and dispersal from sustained low-intensity mono-Inyo eruptions. Bull Volcanol 78:1-13. https://doi.org/10.1007/s00445-016-1053-0

Blake DM, Wilson TM, Gomez C (2016) Road marking coverage by volcanic ash: an experimental approach. Environ Earth Sci 75: 1348. https://doi.org/10.1007/s12665-016-6154-8

Blong RJ (1984) Volcanic hazards. A sourcebook on the effects of eruptions. Academic Press, Sydney

Bonadonna C (2006) Probabilistic modelling of tephra dispersion. In: Mader HM, Coles SG, Connor CB, Connor LJ (eds) Statistics in volcanology. Geological Society of London, London, pp 243-259

Bonadonna C, Biass S, Costa A (2015) Physical characterization of explosive volcanic eruptions based on tephra deposits: propagation of uncertainties and sensitivity analysis. J Volcanol Geotherm Res 296: 80-100. https://doi.org/10.1016/j.jvolgeores.2015.03.009

Bonadonna C, Connor CB, Houghton BF, et al (2005) Probabilistic modeling of tephra dispersal: hazard assessment of a multiphase rhyolitic eruption at Tarawera, New Zealand. J Geophys Res 110:2156-2202

Bonadonna C, Costa A (2012) Estimating the volume of tephra deposits: A new simple strategy. Geology 40:415-418

Bonadonna C, Costa A (2013) Plume height, volume, and classification of explosive volcanic eruptions based on the Weibull function. Bull Volcanol 75:1-19

Bonadonna C, Cioni R, Pistolesi M, et al (2013) Determination of the largest clast sizes of tephra deposits for the characterization of explosive eruptions: a study of the IAVCEI commission on tephra hazard modelling. Bull Volcanol 75:1-15. https://doi.org/10.1007/ s00445-012-0680-3

Bonadonna C, Genco R, Gouhier M et al (2011) Tephra sedimentation during the 2010 Eyjafjallajökull eruption (Iceland) from deposit, radar, and satellite observations. J Geophys Res 116:B12202

Bonadonna C, Houghton B (2005) Total grain-size distribution and volume of tephra-fall deposits. Bull Volcanol 67:441-456

Bonadonna C, Macedonio G, Sparks R (2002) Numerical modelling of tephra fallout associated with dome collapses and Vulcanian explosions: application to hazard assessment on Montserrat. In: Druitt T, Kokelaar B (eds) The eruption of Soufrière Hills Volcano, Montserrat, from 1995 to 1999. Geological Society, London, pp 483-516

Bonne K, Kervyn M, Cascone L et al (2008) A new approach to assess long-term lava flow hazard and risk using GIS and low-cost remote sensing: the case of Mount Cameroon, West Africa. Int J Remote Sens 29:6539-6564

Chester DK, Dibben CJ, Duncan AM (2002) Volcanic hazard assessment in western Europe. J Volcanol Geotherm Res 115:411-435. https:// doi.org/10.1016/S0377-0273(02)00210-X

Commission for the 100-year Memorial of Sakurajima Taisho Eruption (2014) The 100-year memorial of Sakurajima Taisho eruption. Kagoshima

Connor LJ, Connor CB (2006) Inversion is the key to dispersion: understanding eruption dynamics by inverting tephra fallout. In: Mader HM, Coles SG, Connor CB, Connor LJ (eds) Statistics in volcanology. Geological Society of London, London, pp 231-242

Craig H, Wilson T, Stewart C et al (2016a) Agricultural impact assessment and management after three widespread tephra falls in Patagonia, South America. Nat Hazards 82:1167-1229. https://doi. org/10.1007/s11069-016-2240-1

Craig H, Wilson T, Stewart C et al (2016b) Impacts to agriculture and critical infrastructure in Argentina after ashfall from the 2011 eruption of the Cordón Caulle volcanic complex: an assessment of published damage and function thresholds. J Appl Volcanol 5:7. https:// doi.org/10.1186/s13617-016-0046-1 
Cronin SJ, Stewart C, Zernack AV et al (2014) Volcanic ash leachate compositions and assessment of health and agricultural hazards from 2012 hydrothermal eruptions, Tongariro, New Zealand. J Volcanol Geotherm Res. https://doi.org/10.1016/j.jvolgeores.2014.07.002

Dee DP, Uppala SM, Simmons AJ et al (2011) The ERA-Interim reanalysis: configuration and performance of the data assimilation system. Q J R Meteorol Soc 137:553-597. https://doi.org/10.1002/qj.828

Degruyter W, Bonadonna C (2012) Improving on mass flow rate estimates of volcanic eruptions. Geophys Res Lett. https://doi.org/10. 1029/2012GL052566

Deguchi K (1991) Development of a ventilation system against volcanic ash fall in Kagoshima. Energ Buildings 16:663-671. https://doi.org/ 10.1016/0378-7788(91)90035-2

Durand M, Gordon K, Johnston D, et al (2001) Impacts of, and responses to ashfall in Kagoshima from Sakurajima Volcano-lessons for New Zealand. Institute of Geological \& Nuclear Sciences Science Report 2001/30, p 53

Elissondo M, Baumann V, Bonadonna C et al (2016) Chronology and impact of the 2011 Cordón Caulle eruption, Chile. Nat Hazards Earth Syst Sci 16:675-704. https://doi.org/10.5194/nhess-16-675-2016

Engwell SL, Aspinall WP, Sparks RSJ (2015) An objective method for the production of isopach maps and implications for the estimation of tephra deposit volumes and their uncertainties. Bull Volcanol 77: 1-18. https://doi.org/10.1007/s00445-015-0942-y

Engwell SL, Sparks RSJ, Aspinall WP (2013) Quantifying uncertainties in the measurement of tephra fall thickness. J Appl Volcanol 2:1-12. https://doi.org/10.1186/2191-5040-2-5

Favalli M, Tarquini S, Papale P et al (2012) Lava flow hazard and risk at Mt. Cameroon volcano. Bull Volcanol 74:423-439. https://doi.org/ 10.1007/s00445-011-0540-6

Fierstein J, Nathenson M (1992) Another look at the calculation of fallout tephra volumes. Bull Volcanol 54:156-167

Gregg C, Houghton B, Johnston D et al (2004) The perception of volcanic risk in Kona communities from Mauna Loa and Hualalai volcanoes, Hawai'i. J Volcanol Geotherm Res 130:179-196. https://doi.org/10. 1016/S0377-0273(03)00288-9

GSI (2016) GSI. http://www.gsi.go.jp/ENGLISH/. Accessed 20 Feb 2017

Guffanti M, Mayberry GC, Casadevall TJ, Wunderman R (2009) Volcanic hazards to airports. Nat Hazards 51:287-302

Hampton SJ, Cole JW, Wilson G et al (2015) Volcanic ashfall accumulation and loading on gutters and pitched roofs from laboratory empirical experiments: implications for risk assessment. J Volcanol Geotherm Res 304:237-252. https://doi.org/10.1016/j.jvolgeores. 2015.08.012

Hayes J, Wilson TM, Deligne NI et al (2017) A model to assess tephra clean-up requirements in urban environments. J Appl Volcanol 6:1. https://doi.org/10.1186/s13617-016-0052-3

Hayes JL, Wilson TM, Magill C (2015) Tephra fall clean-up in urban environments. J Volcanol Geotherm Res 304:359-377. https://doi. org/10.1016/j.jvolgeores.2015.09.014

Hickey J, Gottsmann J, Nakamichi H, Iguchi M (2016) Thermomechanical controls on magma supply and volcanic deformation: application to Aira caldera, Japan. Sci Rep 6:32691

Hincks TK, Komorowski J-C, Sparks SR, Aspinall WP (2014) Retrospective analysis of uncertain eruption precursors at La Soufrière volcano, Guadeloupe, 1975-77: volcanic hazard assessment using a Bayesian belief network approach. J Appl Volcanol 3: 3. https://doi.org/10.1186/2191-5040-3-3

Igushi M (2013) A precursory process of the 1914 eruption of the Sakurajima volcano inferred from experience of residents. In: IAVCEI 2013 Scientific assembly. Kagoshima

Inman DL (1952) Measures for describing the size distribution of sediments. J Sediment Res 22:125-145

Jenkins SF, Barsotti S, Hincks TK et al (2015a) Rapid emergency assessment of ash and gas hazard for future eruptions at Santorini Volcano, Greece. J Appl Volcanol 4:1-22. https://doi.org/10.1186/s13617-015-0033-y
Jenkins SF, Spence RJS, Fonseca JFBD et al (2014a) Volcanic risk assessment: quantifying physical vulnerability in the built environment. J Volcanol Geotherm Res 276:105-120. https://doi.org/10. 1016/j.jvolgeores.2014.03.002

Jenkins SF, Wilson TM, Magill C, et al (2014b) Volcanic ash fall hazard and risk: technical background paper for the UN-ISDR 2015 global assessment report on disaster risk reduction

Jenkins SF, Wilson TM, Magill C et al (2015b) Volcanic ash fall hazard and risk. In: Loughlin S, Sparks S, Brown S et al (eds) Global Volcanic Hazards and Risk. Cambridge University Press, Cambridge, pp 173-222

Johnston DM, Houghton BF, Neall VE et al (2000) Impacts of the 1945 and 1995-1996 Ruapehu eruptions, New Zealand: an example of increasing societal vulnerability. Geol Soc Am Bull 112:720-726

Kagoshima City (2010) Sakurajima Volcano Hazard Map http://www. city.kagoshima.lg.jp/soumu/shichoshitu/kokusai/en/emergency/ sakurajima.html. Accessed 21 Feb 2017

Klawonn M, Houghton B, Swanson D et al (2014) From field data to volumes: constraining uncertainties in pyroclastic eruption parameters. Bull Volcanol 76:1-16. https://doi.org/10.1007/s00445-014-0839-1

Kobayashi T, Miki D, Sasaki H, et al (2013) Geological map of Sakurajima Volcano, 2nd edn

Kobayashi T, Tameike T (2002) History of eruptions and volcanic damage from Sakurajima volcano, southern Kyushu, Japan. Quat Res 41:269-278

Kotô B (1916) The Great Eruption of Sakura-Jima in 1914. J Coll Sci Tokyo Imp Univ Japan 38:1-334

Macedonio G, Costa A, Folch A (2008) Ash fallout scenarios at Vesuvius: numerical simulations and implications for hazard assessment. J Volcanol Geotherm Res 178:366-377. https://doi.org/10. 1016/j.jvolgeores.2008.08.014

Machida H (2002) Volcanoes and tephras in the Japan area. Glob Environ Res 6:19-28

Maeno F, Nagai M, Nakada S et al (2014) Constraining tephra dispersion and deposition from three subplinian explosions in 2011 at Shinmoedake volcano, Kyushu, Japan. Bull Volcanol 76:1-16. https://doi.org/10.1007/s00445-014-0823-9

Magill C, Wilson T, Okada T (2013) Observations of tephra fall impacts from the 2011 Shinmoedake eruption, Japan. Earth Planets Space 65:677-698. https://doi.org/10.5047/eps.2013.05.010

Marrero JM, Garcia A, Llinares A et al (2010) The Variable Scale Evacuation Model (VSEM): a new tool for simulating massive evacuation processes during volcanic crises. Nat Hazards Earth Syst Sci 10:747-760

Marti J, Spence R, Calogero E et al (2008) Estimating building exposure and impact to volcanic hazards in Icod de los Vinos, Tenerife (Canary Islands). J Volcanol Geotherm Res 178:553-561

Marzocchi W, Newhall C, Woo G (2012) The scientific management of volcanic crises. J Volcanol Geotherm Res 247-248:181-189. https:// doi.org/10.1016/j.jvolgeores.2012.08.016

McDonald GW, Smith NJ, Kim J et al (2017) The spatial and temporal "cost" of volcanic eruptions: assessing economic impact, business inoperability, and spatial distribution of risk in the Auckland region, New Zealand. Bull Volcanol 79:48. https://doi.org/10.1007/s00445017-1133-9

Meier P (2012) Crisis mapping in action: how open source software and global volunteer networks are changing the world, one map at a time. J Map Geogr Libr 8:89-100. https://doi.org/10.1080/ 15420353.2012.663739

Metzger P, D'Ercole R, Sierra A (1999) Political and scientific uncertainties in volcanic risk management: the yellow alert in Quito in October 1998. GeoJournal 49:213-221

Ministry of Agriculture Forestry and Fishery (2010) Report on results of 2010 World Census of Agriculture and Forestry in Japan http:// www.maff.go.jp/e/data/stat/index.html. Accessed 1 Dec 2016

Miyabuchi Y, Hanada D, Niimi H, Kobayashi T (2013) Stratigraphy, grain-size and component characteristics of the 2011 Shinmoedake 
eruption deposits, Kirishima Volcano, Japan. J Volcanol Geotherm Res 258:31-46. https://doi.org/10.1016/j.jvolgeores.2013.03.027

Newhall CG, Self S (1982) The volcanic explosivity index (VEI) - an estimate of explosive magnitude for historical volcanism. J Geophys Res 87:1231-1238

Omori F (1914) The Sakura-Jima eruptions and earthquakes. Bull Imp Earthq Investig Comm 8:1-630

OpenFlights.org (2016) OpenFlights.org. http://openflights.org. Accessed 20 Feb 2017

Ort MH, Elson MD, Anderson KC et al (2008) Effects of scoria-cone eruptions upon nearby human communities. Geol Soc Am Bull 120: 476-486. https://doi.org/10.1130/B26061.1

OSM (2016) Open Street Map. http://www.openstreetmap.org/. Accessed $20 \mathrm{Feb} 2017$

Oze C, Cole J, Scott A et al (2014) Corrosion of metal roof materials related to volcanic ash interactions. Nat Hazards 71:785-802. https://doi.org/10.1007/s11069-013-0943-0

Pomonis A, Spence R, Baxter P (1999) Risk assessment of residential buildings for an eruption of Furnas Volcano, Sao Miguel, the Azores. J Volcanol Geotherm Res 92:107-131

Pyle D (1989) The thickness, volume and grainsize of tephra fall deposits. Bull Volcanol 51:1-15

QGIS Development Team (2016) QGIS Geographic Information System

Renschler CS (2005) Scales and uncertainties in using models and GIS for volcano hazard prediction. J Volcanol Geotherm Res 139:73-87. https://doi.org/10.1016/j.jvolgeores.2004.06.016

Sabo and Landslide Technical Center (2007) Sakurajima wide-area disaster prevention map. http://www.qsr.mlit.go.jp/osumi/files/Content/ 234/pdf/150424_bousai map.pdf. Accessed 21 Feb 2017

Sandri L, Costa A, Selva J et al (2016) Beyond eruptive scenarios: assessing tephra fallout hazard from Neapolitan volcanoes. Sci Rep 6:24271

Scaini C, Biass S, Galderisi A et al (2014) A multi-scale risk assessment for tephra fallout and airborne concentration from multiple Icelandic volcanoes - part 2: vulnerability and impact. Nat Hazards Earth Syst Sci 14:2289-2312. https://doi.org/10.5194/nhess-14-2289-2014

Scaini C, Folch A, Navarro M (2012) Tephra hazard assessment at Concepción Volcano, Nicaragua. J Volcanol Geotherm Res 219220:41-51

Scollo S, Tarantola S, Bonadonna C et al (2008) Sensitivity analysis and uncertainty estimation for tephra dispersal models. J Geophys Res Solid Earth 113:B06202

Selva J, Costa A, Marzocchi W, Sandri L (2010) BET_VH: exploring the influence of natural uncertainties on long-term hazard from tephra fallout at Campi Flegrei (Italy). Bull Volcanol 72:717-733

Sheldrake T, Caricchi L (2016) Regional variability in the frequency and magnitude of large explosive volcanic eruptions. Geology. https:// doi.org/10.1130/G38372.1

Spence RJS, Kelman I, Baxter PJ et al (2005) Residential building and occupant vulnerability to tephra fall. Nat Hazards Earth Syst Sci 5:477-494

Stewart C, Craig HM, Gaw S et al (2016) Fate and agricultural consequences of leachable elements added to the environment from the 2011 Cordón Caulle tephra fall. J Volcanol Geotherm Res. https:// doi.org/10.1016/j.jvolgeores.2016.09.017

Sword-Daniels V, Wilson TM, Sargeant S et al (2014) Chapter 26 consequences of long-term volcanic activity for essential services in Montserrat: challenges, adaptations and resilience. Geol Soc London, Mem 39:471-488

Tajima Y, Tamura K, Yamakoshi T et al (2013) Ellipse-approximated isopach maps for estimating ashfall volume at Sakurajima Volcano. Bull Volc Soc Japan 58:291-306

Thompson MA, Lindsay JM, Wilson TM et al (2016) Quantifying risk to agriculture from volcanic ashfall: a case study from the Bay of
Plenty, New Zealand. Nat Hazards 86:31-56. https://doi.org/10. 1007/s11069-016-2672-7

Todde A (2016) The Plinian activity of Sakurajima volcano (Japan) in the last six centuries: stratigraphy and dynamics of Bunmei, Anei and Taisho eruptions. Universita degli studi Firenze

Todde, R. Cioni, M. Pistolesi, N. Geshi, C. Bonadonna (2017) The 1914 Taisho eruption of Sakurajima volcano: stratigraphy and dynamics of the largest explosive event in Japan during the twentieth century. Bull Volcanol. https://doi.org/10.1007/s00445-017-1154-4

United Nations Statistics Division (2005) Demographic yearbook. http:// unstats.un.org/unsd/demographic/products/dyb/dyb2005.htm

Volentik ACM, Bonadonna C, Connor CB et al (2010) Modeling tephra dispersal in absence of wind: insights from the climactic phase of the 2450BP Plinian eruption of Pululagua volcano (Ecuador). J Volcanol Geotherm Res 193:117-136. https://doi.org/10.1016/j. jvolgeores.2010.03.011

Volentik ACM, Connor CB, Connor LJ, Bonadonna C (2009) Aspects of volcanic hazards assessment for the Bataan nuclear power plant, Luzon Peninsula, Philippines. In: Connor C, Chapman NA, Connor L (eds) Volcanic and tectonic hazard assessment for nuclear facilities. Cambridge University Press, Cambridge

Volentik AM, Houghton B (2015) Tephra fallout hazards at Quito International Airport (Ecuador). Bull Volcanol 77:1-14. https://doi. org/10.1007/s00445-015-0923-1

Wardman J, Wilson T, Bodger P, et al (2012) Investigating the electrical conductivity of volcanic ash and its effect on HV power systems. Phys Chem Earth, Parts A/B/C 45-46:128-145

Wilson G, Wilson T, Cole J, Oze C (2012b) Vulnerability of laptop computers to volcanic ash and gas. Nat Hazards 63:711-736. https://doi. org/10.1007/s11069-012-0176-7

Wilson G, Wilson TM, Deligne NI, Cole JW (2014) Volcanic hazard impacts to critical infrastructure: a review. J Volcanol Geotherm Res 286:148-182. https://doi.org/10.1016/j.jvolgeores.2014.08.030

Wilson T, Cole J, Cronin S, Stewart C (2011a) Impacts on agriculture following the 1991 eruption of Vulcan Hudson, Patagonia: lessons for recovery. Nat Hazards 57:185-212

Wilson T, Stewart C, Bickerton H, et al (2013) Impacts of the June 2011 Puyehue-Cordón Caulle volcanic complex eruption on urban infrastructure, agriculture and public health

Wilson T, Stewart C, Sword-Daniels V, et al (2012a) Volcanic ash impacts on critical infrastructure. Phys Chem Earth, Parts A/B/C 45-46:5-23

Wilson TM, Cole JW, Stewart C et al (2011b) Ash storms: impacts of wind-remobilised volcanic ash on rural communities and agriculture following the 1991 Hudson eruption, southern Patagonia, Chile. Bull Volcanol 73:223-239

Yasui M, Takahashi M, Shimada J et al (2013) Comparative study of proximal eruptive events in the large-scale eruption of Sakurajima: An-ei eruption vs. Taisho eruption. Bull Volcanol Soc Japan 58:59-76

Yokoama I (1997) An interpretation of the 1914 eruption of Sakurajima volcano. Proc Japan Acad Ser B 73:53-58. https://doi.org/10.2183/ pjab. 73.53

Zook M, Graham M, Shelton T, Gorman S (2010) Volunteered geographic information and crowdsourcing disaster relief: a case study of the Haitian earthquake. World Med Heal Policy 2:7-33. https://doi.org/ 10.2202/1948-4682.1069

Zorn E, Walter TR (2016) Influence of volcanic tephra on photovoltaic (PV)-modules: an experimental study with application to the 2010 Eyjafjallajökull eruption, Iceland. J Appl Volcanol 5:2. https://doi. org/10.1186/s13617-015-0041-y

Zuccaro G, De Gregorio D, Baxter P (2015) Human and structural vulnerability to volcanic processes. In: Papale P (ed) Volcanic hazards, risks, and disasters. Elsevier Inc., pp 261-288 